\title{
Variability of BVOC emissions from a Mediterranean mixed forest in southern France with a focus on Quercus pubescens
}

\author{
A.-C. Genard-Zielinski ${ }^{1,2}$, C. Boissard ${ }^{2}$, C. Fernandez ${ }^{1}$, C. Kalogridis ${ }^{2}$, J. Lathière ${ }^{2}$, V. Gros ${ }^{2}$, N. Bonnaire ${ }^{2}$, and \\ E. Ormeño ${ }^{1}$ \\ ${ }^{1}$ IMBE, Aix Marseille Université-CNRS-IRD-Univ. Avignon 3 Place Victor Hugo, 13331 Marseille CEDEX 3, France \\ ${ }^{2}$ Laboratoire des Sciences du Climat et de l'Environnement (LSCE-IPSL), Unité Mixte CEA-CNRS-UVSQ (Commissariat à \\ l'Energie Atomique, Centre National de la Recherche Scientifique, Université de Versailles Saint-Quentin-en-Yvelines), \\ 91198 Gif-sur-Yvette, France
}

Correspondence to: C. Boissard (christophe.boissard@1sce.ipsl.fr)

Received: 6 May 2014 - Published in Atmos. Chem. Phys. Discuss.: 27 June 2014

Revised: 21 October 2014 - Accepted: 13 November 2014 - Published: 14 January 2015

\begin{abstract}
We aimed at quantifying biogenic volatile organic compound (BVOC) emissions in June from three Mediterranean species located at the $\mathrm{O}_{3} \mathrm{HP}$ site (southern France): Quercus pubescens, Acer monspessulanum and C. coggygria (for isoprene only). As $Q$. pubescens was shown to be the main BVOC emitter with isoprene representing $\approx 99 \%$ of the carbon emitted as BVOC, we mainly focused on this species. C. coggygria was found to be a non-isoprene emitter (no other BVOCs were investigated).
\end{abstract}

To fully understand both the canopy effect on $Q$. pubescens isoprene emissions and the inter-individual variability (tree to tree and within canopy), diurnal variations of isoprene were investigated from nine branches (seven branches located to the top of canopy at $\approx 4 \mathrm{~m}$ above ground level (a.g.l.), and two inside the canopy at $\approx 2 \mathrm{~m}$ a.g.l.).

The $Q$. pubescens daily mean isoprene emission rate $\left(\mathrm{ER}_{\mathrm{d}}\right)$ fluctuated between 23 and $98 \mu \mathrm{gC} \mathrm{g}_{\mathrm{DM}}^{-1} \mathrm{~h}^{-1}$. Q. pubescens daily mean net assimilation $(\mathrm{Pn})$ ranged between 5.4 and 13.8, and 2.8 and $6.4 \mu \mathrm{mol} \mathrm{CO}_{2} \mathrm{~m}^{-2} \mathrm{~s}^{-1}$ for sunlit and shaded branches respectively. Both $\mathrm{ER}_{\mathrm{d}}$ and isoprene emission factors (Is), assessed according to Guenther et al. (1993) algorithm, varied by a factor of 4.3 among the sunlit branches. While sunlit branches $E_{d}$ was clearly higher than for shaded branches, there was a non-significant variability of Is (59 to $77 \mu \mathrm{gC} \mathrm{g}_{\mathrm{DM}}^{-1} \mathrm{~h}^{-1}$ ). Diurnal variations of isoprene emission rates (ERs) for sunlit branches were also investigated. ERs were detected at dawn $2 \mathrm{~h}$ after Pn became positive and were mostly exponentially dependent on Pn. Diurnal variations of ERs were not equally well described throughout the day by temperature $\left(C_{\mathrm{T}}\right)$ and light $\left(C_{\mathrm{L}}\right)$ parameters according to G93 algorithm. Temperature had more impact than photosynthetically active radiation (PAR) on the morning emissions increase, and ER was no longer correlated to $C_{\mathrm{L}} \times C_{\mathrm{T}}$ between solar noon (maximum ER) and mid-afternoon, possibly due to thermal stress of the plant. A comparison between measured and calculated emissions using two isoprene algorithms (G93 and MEGAN - Model of Emissions of Gases and Aerosols from Nature) highlighted the importance of isoprene emission factor Is value used, and some weakness in assessing isoprene emissions under Mediterranean climate conditions (drought) with current isoprene models.

\section{Introduction}

Isoprene (2-methylbuta-1,3-diene) is the most abundant biogenic volatile organic compound (BVOC) released into the atmosphere with a global annual flux estimation of 400$660 \mathrm{TgC} \mathrm{yr}^{-1}$ (Guenther et al., 2006). Once in the atmosphere and due to the high quantity emitted, isoprene strongly impacts the atmospheric chemistry. Indeed, this molecule is going to react quickly with the main oxidant compound $(\mathrm{OH})$, leading to the formation of oxidative highly reactive products in the atmosphere (Atkinson, 2000; Ciccioli et al., 1999; Claeys et al., 2004; Steiner and Goldstein, 2007).

At a smaller scale, isoprene plays a key role in the tropospheric chemistry since, like other VOCs, it is an ozone pre- 
cursor in the presence of $\mathrm{NO}_{\mathrm{x}}$ and light (Atkinson, 2000). $\mathrm{NO}_{\mathrm{x}}$ being mainly emitted by anthropogenic sources, isoprene emissions occurring close to megacities surrounded by large ecosystem areas (such as the Mediterranean) can significantly contribute to high $\mathrm{O}_{3}$ levels in summer (Curci et al., 2009).

Isoprene emissions are well recognised to be strongly driven by temperature and light conditions. Indeed, without any other environmental constraints, these two parameters drive the diurnal cycle of isoprene emissions (Guenther et al., 1991). More precisely, light affects the photosynthetic processes which, in turn, impact the quantity of isoprene precursor (especially glyceraldehyde 3-phosphate) for isoprene synthesis, and temperature increases isoprene synthase activity (Niinemets et al., 2010b). As a result, it was shown that the branch location inside a canopy is an important source of isoprene emission variability, with significantly lower isoprene emissions from shaded branches inside the canopy compared to sunlit branches at the top of the canopy (Harley et al., 1994; Monson and Fall, 1989).

However, other factors can explain isoprene emission variability. In particular, the capacity to emit isoprene (or emission factor Is) is intrinsically bound to the plant species. Guenther et al. (1994) proposed therefore to divide isoprene emitter species into four groups with negligible $\left(<0.1 \mu \mathrm{gC} \mathrm{g} \mathrm{DM}^{-1} \mathrm{~h}^{-1}\right)$, low $\left(14 \pm 7 \mu \mathrm{gC} \mathrm{g}_{\mathrm{DM}}^{-1} \mathrm{~h}^{-1}\right)$, moderate $\left(35 \pm 17 \mu \mathrm{gC} \mathrm{g} \mathrm{DM}^{-1} \mathrm{~h}^{-1}\right)$ and high $\left(>70 \pm 35 \mu \mathrm{gCg} \mathrm{g}_{\mathrm{DM}}^{-1} \mathrm{~h}^{-1}\right)$ emitter species.

In Europe, Quercus pubescens Willd. is one of the most important isoprene emitter species, and represents thus one of the most significant biogenic isoprene sources in the Mediterranean region (Keenan et al., 2009). Previously reported Is values were observed to vary for this species in the Mediterranean area over a large range. Kesselmeier et al. (1998) and Owen et al. (1998) assessed a fairly similar Is of 50 and $66 \mu \mathrm{gC} \mathrm{g}_{\mathrm{DM}}^{-1} \mathrm{~h}^{-1}$ respectively at a site near Montpellier (France), which was $50 \%$ lower than what Simon et al. (2005) found $250 \mathrm{~km}$ from this site. On the other hand, Steinbrecher et al. (2013) observed a remarkable Is stability from seedlings of various oak species (including Q. pubescens) originating from different environmental climates (precipitation, temperature) and coming from different European sites. Simpson et al. (1999) proposed in their European BVOC inventory review an Is value of $53 \mu \mathrm{gCg}_{\text {DM }}^{-1} \mathrm{~h}^{-1}$ for $Q$. pubescens.

This emission factor variability represents one of the main uncertainties of BVOC emission models. Parameters such as edaphic conditions, natural hybridisation between plant species, and environmental tree history have been suggested to impact the overall capacity of a plant to emit isoprene.

This study was part of the CANOPÉE project which aimed at analysing and quantifying intra-canopy processes in the reactive organic compound exchange between the biosphere and the atmosphere, with a focus on isoprene (further de- tails can be found at https://wiki.lsce.ipsl.fr/canopee/doku. php?id=links). An intensive field campaign took place at the Oak Observatory at $\mathrm{OHP}\left(\mathrm{O}_{3} \mathrm{HP}\right)$, a Mediterranean site located in southern France.

Our objectives during this campaign were (i) to extensively screen, at the branch scale and using dynamic enclosures, BVOC emissions from the $\mathrm{O}_{3} \mathrm{HP}$ forest, with a focus on $Q$. pubescens and, to a lesser extent, Acer monspessulanum L., whose emission data have never been reported so far; Cotinus coggygria was also investigated in terms of isoprene alone; (ii) to survey the canopy variability (tree to tree and within the canopy) and (iii) the diurnal variability of $Q$. pubescens isoprene emissions and (iv) to test the ability of two commonly used algorithms to assess, under Mediterranean climate constraints, the observed diurnal variations of isoprene emission.

\section{Methods}

\subsection{Experimental site}

BVOC measurements took place at the $\mathrm{O}_{3} \mathrm{HP}$ experimental site located in the research centre Observatoire de Haute Provence, $60 \mathrm{~km}$ north of Marseille $\left(5^{\circ} 42^{\prime} 44^{\prime \prime} \mathrm{E}\right.$, $43^{\circ} 55^{\prime} 54^{\prime \prime} \mathrm{N}$ ), at an elevation of $650 \mathrm{~m}$ above mean sea level (a.m.s.l.). The $\mathrm{O}_{3} \mathrm{HP}\left(955 \mathrm{~m}^{2}\right)$, free from human disturbance for 70 years, consists of a flat homogeneous forest mainly composed of $Q$. pubescens $(\approx 90 \%$ of the biomass and $\approx 75 \%$ of the trees). The remaining $10 \%$ of the biomass is mainly represented by $A$. monspessulanum trees. The mean $Q$. pubescens diameter at $1.3 \mathrm{~m}$ is $8.8 \mathrm{~cm}(n=272)$ and the stage of the whole canopy closure was assessed by a mean leaf area index of 2.2. Dry leaf production was assessed for $Q$. pubescens to range between 1.4 and $1.6 \mathrm{tha}^{-1} \mathrm{yr}^{-1}$. The $\mathrm{O}_{3} \mathrm{HP}$ site was created in 2009 in order to study the downy oak ( $Q$. pubescens) forest ecosystem at soil and tree scale, under both natural and accentuated water stress conditions (a control and a rain exclusion plot respectively) induced by a rainfall exclusion device (an automated monitored roof deployed during rain events) set up over a part of the $\mathrm{O}_{3} \mathrm{HP}$ canopy. A dense network of sensors in the soil, under and over the canopy, continuously recorded the climatic and edaphic parameters (air and soil temperatures and relative humidity, photosynthetically active radiation or PAR). A two-level metallic scaffold allows the canopy access at two heights (under the canopy at $0.8 \mathrm{~m}$ and at the top of the canopy at $4 \mathrm{~m}$ ). For further details see https://o3hp.obs-hp.fr/ index.php/fr/.

\subsection{Sampling strategy}

The experiment took place from 29 May to 19 June 2012. A total of nine different $Q$. pubescens and one A. monspessulanum were studied for isoprene emissions during the cam- 
paign. C. coggygria was found to be a non-isoprene emitter (no other BVOCs were investigated).

At the beginning of the campaign, in order to screen the composition of BVOC emissions and monitor diurnal variations over a $24 \mathrm{~h}$ period, a PTR-MS (proton transfer reactionmass spectrometry) was connected to an enclosure system (described below) set up on one A. monspessulanum and one $Q$. pubescens sunlit branch (Am, 2 June and $Q p 4,1$ June respectively). $A m$ and $Q p 4$ were located in a clearing $40 \mathrm{~m}$ north of the $\mathrm{O}_{3} \mathrm{HP}$ scaffold (Fig. 1) close to where the PTRMS system was set up during the CANOPÉE campaign (see Kalogridis et al., 2014).

To further investigate the variability of isoprene emissions at the canopy scale, two strategies were undertaken.

On the one hand, tree-to-tree variability was evaluated by studying three healthy and sunlit $Q$. pubescens branches within the control $(Q p 1, Q p 2, Q p 3)$ and the rain exclusion $(Q p 5, Q p 6, Q p 7)$ plot. On the other hand, variability of isoprene emissions between shaded and sunlit branches was assessed on $Q p 1$ and $Q p 2$. In addition to a sunlit branch, a shaded branch was also studied for those two trees, approximately $2 \mathrm{~m}$ above ground $\left(Q p 1_{\text {shade }}\right.$ and $\left.Q p 2_{\text {shade }}\right)$. Isoprene samples were collected on adsorbent cartridges.

When cartridges were used, isoprene emissions were sampled approximately hourly from sunrise to sunset. One of the enclosures was maintained on the $Q p 1$ branch during the whole campaign (15 days) in order to follow continuous diurnal variations of isoprene emission rates during the concomitant isoprene canopy flux measurements carried out by Kalogridis et al. (2014). The second enclosure was used to alternatively investigate, over 1 to 2 days, isoprene emissions from the other eight branches selected (sunlit and shaded). Concomitant microclimate (PAR, temperature, relative humidity) and physiological parameters (net photosynthesis Pn and stomatal conductance to water $\mathrm{Gw}$ ) were continuously monitored during the BVOC sampling.

No other A. monspessulanum branches were studied since the online PTR-MS screening revealed very low BVOC emissions.

\subsection{Branch-scale sampling methods}

Dynamic branch enclosures were used for sampling BVOCs. Branches (mature leaves $\approx 3$ months old) were enclosed in $\mathrm{a} \approx 60$ L PTFE (polytetrafluoroethylene) frame closed by a sealed $50 \mu \mathrm{m}$ thick PTFE film to which ambient air was introduced at $11-14 \mathrm{~L} \mathrm{~min}^{-1}$ using a PTFE pump (KNF N840.1.2FT.18 ${ }^{\circledR}$, Germany). A PTFE propeller ensured a rapid mixing of the chamber air and a slight positive pressure within the enclosure enabled it to be held away from the leaves to minimise damage to the biomass. Microclimate (PAR, temperature, relative humidity) inside the chamber was continuously (every minute) monitored by a data logger (LI-COR $1400^{\circledR}$; Lincoln, NE, USA) coupled to a RHT probe (relative humidity and temperature, LI-COR 1400-
$04^{\circledR}$, Lincoln, NE, USA) and a quantum sensor (LI-COR, PAR-SA $190^{\circledR}$, Lincoln, NE, USA); the latter sensor was set up and maintained horizontally in the enclosure and located close to the leaves. $\mathrm{CO}_{2} / \mathrm{H}_{2} \mathrm{O}$ exchanges from the enclosed branches were also continuously measured using infrared gas analysers (IRGA $840 \mathrm{~A}^{\circledR}$, LI-COR).

$\mathrm{Pn}\left(\mu \mathrm{mol}_{\mathrm{CO}_{2}} \mathrm{~m}^{-2} \mathrm{~s}^{-1}\right)$ was calculated using equations described by Von Caemmerer and Farquhar (1981) as follows:

$\mathrm{Pn}=\frac{F \times(\mathrm{Cr}-\mathrm{Cs})}{S}-\mathrm{Cs} \times E$,

where $F$ is the incoming air flow rate $\left(\mathrm{mol} \mathrm{s}^{-1}\right)$, Cs and $\mathrm{Cr}$ are the sample and reference $\mathrm{CO}_{2}$ molar fractions respectively $\left(\mu \mathrm{mol}_{\mathrm{CO}_{2}} \mathrm{~mol}^{-1}\right.$ or $\left.\mathrm{ppm}\right), S$ is the leaf area $\left(\mathrm{m}^{2}\right)$, $\mathrm{Cs} \times E$ is the fraction of $\mathrm{CO}_{2}$ diluted in the water evapotranspirated $\left(\mu \mathrm{mol}_{\mathrm{CO}_{2}} \mathrm{~m}^{-2} \mathrm{~s}^{-1}\right)$ and $E$ is the transpiration rate $\left(\right.$ mol $\left._{\mathrm{H}_{2} \mathrm{O}} \mathrm{m}^{-2} \mathrm{~s}^{-1}\right)$ calculated as follows:

$E=\frac{F \times(\mathrm{Ws}-\mathrm{Wr})}{S \times(1-\mathrm{Ws})}$,

where Ws and $\mathrm{Wr}$ are the sample and reference $\mathrm{H}_{2} \mathrm{O}$ molar fractions respectively $\left(\mathrm{mol}_{\mathrm{H}_{2} \mathrm{O}} \mathrm{mol}^{-1}\right)$.

$\mathrm{Gw}\left(\mathrm{mol}_{\mathrm{H}_{2} \mathrm{O}} \mathrm{m}^{-2} \mathrm{~s}^{-1}\right)$ was calculated using the following equation

$G w=\frac{E \times\left(1-\frac{\mathrm{Wl}+\mathrm{Ws}}{2}\right)}{\mathrm{Wl}-\mathrm{Ws}}$,

where $E$ and Ws are described in Eq. (2), Wl is the molar concentration of water vapour within the leaf $\left(\mathrm{mol}_{\mathrm{H}_{2} \mathrm{O}} \mathrm{mol}^{-1}\right)$ calculated using the equation

$W l=\frac{\mathrm{VP}_{\mathrm{sat}}}{P}$,

where $\mathrm{VP}_{\text {sat }}$ is the saturated vapour pressure $(\mathrm{kPa})$, and $P$ is the atmospheric pressure $(\mathrm{kPa})$.

Air flow rates were controlled by mass flow controllers (Bronkhorst) and all tubing lines were made of PTFE.

Total dry biomass matter (DM) was assessed during this study for each sampled branch by manually scanning every leaf enclosed in the chamber and applying an area factor (AF) conversion extrapolated from concomitant measurements made on the same site. For top and shaded canopy branches, mean (range) DM measured during this study was $0.16(0.01-0.45)$ and $0.10(0.01-0.38) \mathrm{g}_{\mathrm{DM}}$ respectively, and mean (range) AF was 13.17 (0.82-36.67) and 11.98 (2.10$41.85) \mathrm{cm}^{-2}$ respectively. A mean leaf-to-mass-area ratio (LMA) of $123.2 \pm 1.0(n=5$ trees $)$ and $87.1 \pm 1.8 \mathrm{~g}_{\mathrm{DM}} \mathrm{m}^{-2}$ ( $n=15$ trees) was then assessed for sunlit and shaded branches respectively. Since the sampled A. monspessulanum was not located into the protected $\mathrm{O}_{3} \mathrm{HP}$ site, DM was assessed directly by cutting off the branch, drying and weighting foliar biomass; LMA was $75.4 \mathrm{~g}_{\mathrm{DM}} \mathrm{m}^{-2}$. 
Branch enclosures were mostly installed on the previous day before the first emission rate measurement took place and at least $2 \mathrm{~h}$ before.

For BVOC screening, the PTR-MS was connected to the enclosure system with a $25 \mathrm{~m}$ length $1 / 4$ in PTFE tubing (not heated) in order to follow, online, the rapid diurnal variations of BVOC emission rates from a $Q$. pubescens and an A. monspessulanum branch; flow rate entering the chamber was fixed at $14.7 \mathrm{~L} \mathrm{~min}^{-1}$ (for details of PTR-MS system see Kalogridis et al., 2014).

Due to the number of samples collected during this study, BVOCs sampled on cartridges were analysed by the two partnered laboratories (IMBE, LSCE) using very similar analytical techniques. BVOC concentrations were measured in both the inflowing and the outflowing air by passing the air through adsorbent cartridges at $0.1 \mathrm{~L} \mathrm{~min}^{-1}$ for $1-$ 3 min: Chrompack glass tubes $6.1 \mathrm{~mm}$ OD (outside diameter), $150 \mathrm{~mm}$ length packed with $0.06 \mathrm{~g}$ Tenax TA and $0.14 \mathrm{~g}$ Carbotrap B, and Perkin Elmer stainless-steel (SS) tubes $6.1 \mathrm{~mm}$ OD, $90 \mathrm{~mm}$ length packed with $0.3 \mathrm{~g}$ Tenax TA for IMBE and LSCE respectively. Sampling rates were controlled by mass flow controllers. Before measurement, tubes were preconditioned at $300^{\circ} \mathrm{C}$ for $2-3 \mathrm{~h}$ under continuous helium purge. During sampling, glass tubes were protected from direct sunlight with aluminium foil. Tubes were removed from a cold box located close to the enclosures just before the measurements. Subsequent to sampling, tubes were sealed with Swagelock end caps and PTFE ferrules and stored at $4{ }^{\circ} \mathrm{C}$ before laboratory analysis within the following 3 weeks. Ozone was removed from sampled air by placing PTFE filters impregnated with sodium thiosulfate $\left(\mathrm{Na}_{2} \mathrm{~S}_{2} \mathrm{O}_{3}\right)$ onto the sampling lines accordingly to Pollmann et al. (2005).

BVOC emission rates (ERs) using PTR-MS and cartridges were calculated by considering the BVOC concentrations in the inflowing and outflowing air as

$\mathrm{ER}=Q_{0} \times\left(C_{\text {out }}-C_{\text {in }}\right) \times B^{-1}$,

where ER is expressed in $\mu \mathrm{gCg}_{\mathrm{DM}}^{-1} \mathrm{~h}^{-1}, Q_{0}$ is the flow rate of the air introduced into the chamber $\left(\mathrm{L} \mathrm{h}^{-1}\right), C_{\text {out }}$ and $C_{\text {in }}$ are the concentrations in the inflowing and outflowing air $\left(\mu \mathrm{gCL}^{-1}\right)$ and $B$ is the total dry biomass matter $\left(\mathrm{g}_{\mathrm{DM}}\right)$.

Intercomparison exercises between isoprene determination using both IMBE and LSCE cartridges and the online PTR-MS showed a mean difference (bias) between 4.0 and $8.6 \%$.

In addition to these parameters recorded inside the enclosures, daily mean PAR, temperature and relative humidity were recorded above the canopy $(6 \mathrm{~m})$ during the campaign and are presented in Fig. 2a together with the mean daily soil water content (Sw, Fig. 2b) obtained in the control and the rain exclusion plots (mean of six and five different probes respectively).

\subsection{Analytical methods}

BVOCs collected in glass and SS cartridges were analysed using similar gas chromatography-mass spectrometry (GCMS) techniques.

Glass tubes were analysed with a gas chromatograph (GC, HP $6890 \mathrm{~N}^{\circledR}$ ) coupled to a thermal desorption injector (Gerstel, TDS3/CIS $\left.4{ }^{\circledR}\right)$ and a quadrupole mass selective detector (MSD, HP $5973^{\circledR}$ ). Sampling tubes were thermally desorbed at $250{ }^{\circ} \mathrm{C}$ with carrier gas (He) flowing at $50 \mathrm{~mL} \mathrm{~min}^{-1}$ for $10 \mathrm{~min}$. Isoprene was re-concentrated onto a Carbotrap B cold trap maintained at $-50^{\circ} \mathrm{C}$. Secondary desorption was set up at $250^{\circ} \mathrm{C}$ for $3 \mathrm{~min}$. An $\mathrm{Al} / \mathrm{KCl}$ capillary-type column $(30 \mathrm{~m} \times 0.250 \mathrm{~mm}$ ID (inner diameter), $5 \mu \mathrm{m}$ thickness film) was used for the analysis using helium (5.6, Linde gas) as carrier gas at $1 \mathrm{~mL} \mathrm{~min}^{-1}$ and the following temperature program: $40^{\circ} \mathrm{C}(1 \mathrm{~min})$ to $200^{\circ} \mathrm{C}(1 \mathrm{~min})$ at $20^{\circ} \mathrm{C} \mathrm{min}^{-1}$. The MS detector was set up at $250^{\circ} \mathrm{C}$ in scan mode with $\mathrm{m} / \mathrm{z}$ ranging from 40 to $150 \mathrm{amu}$. The isoprene detection limit was $0.015 \mathrm{ng}$ on column, corresponding to $3 \mathrm{pptv}$ in air for a $1 \mathrm{~L}$ sample, with a level of analytical precision better than $5 \%$. Under sampling conditions (similar flow rate, volume, biomass), 3 pptv corresponds to a minimum emission rate of $0.003 \mu \mathrm{gC} \mathrm{g} \mathrm{g}_{\mathrm{DM}}^{-1} \mathrm{~h}^{-1}$. Isoprene quantification was achieved using a $5.00 \pm 0.25 \mathrm{ppm}$ diluted in $\mathrm{N}_{2}$ certified gas standard (Air Liquide). Desorption and quantitative analysis of BVOCs from SS sampling tubes was carried out using a Perkin Elmer ATD-300 automatic thermal desorption unit connected via a transfer line heated at $220^{\circ} \mathrm{C}$ to a Varian CP 3800 GC connected to a MSD, Varian Saturn $2200 \mathrm{MSD}$. Compound desorption started at $225^{\circ} \mathrm{C}$ for $10 \mathrm{~min}$ at $30 \mathrm{~mL} \mathrm{~min}^{-1}$ onto a mixed Carbotrap B and Carbosieve SII cold trap maintained at $0{ }^{\circ} \mathrm{C}$. Secondary desorption was at $300^{\circ} \mathrm{C}$ for $1 \mathrm{~min}$. Compound separation was achieved using a fused silica capillary $(25 \mathrm{~m} \times 0.25 \mathrm{~mm}$ ID coated with PoraBOND Q) porous layer open tubular column (PLOT). Initial oven column was $50^{\circ} \mathrm{C}$ maintained for $3 \mathrm{~min}$ and then increased at $5^{\circ} \mathrm{Cmin}^{-1}$ up to $250^{\circ} \mathrm{C}$ maintained for $10 \mathrm{~min}$. The carrier gas was helium $\mathrm{N} 6$ at $1.2 \mathrm{~mL} \mathrm{~min}^{-1}$. Samples were analysed in total ion current mode, with $\mathrm{m} / \mathrm{z}$ ranging from 20 to 250 . The detection limit was 0.006 and $0.10 \mathrm{ng}$ on column for isoprene and monoterpene respectively, corresponding to 1.2 and 40 pptv respectively in air for a $1 \mathrm{~L}$ sample, with a level of analytical precision better than $7.5 \%$. Under sampling conditions (similar flow rate, volume, biomass) this corresponds to a minimum isoprene (monoterpene) emission rate of $0.0025 \mu \mathrm{gCg}_{\mathrm{DM}}^{-1} \mathrm{~h}^{-1}$. Isoprene quantification was made using a $3.97 \pm 0.08 \mathrm{ppb}$ in $\mathrm{N}_{2}$ certified gas standard (NPL, Teddington Middlesex, UK) for lower concentrations and a $3.90 \pm 0.29 \mathrm{ppm}$ in $\mathrm{N}_{2}$ certified gas standard (Air Liquide) for higher concentrations. Monoterpene quantification was made by comparison with liquid standard (Fluka) appropriately diluted in $\mathrm{MeOH}$. GCMS quantification was made for the ion $m / z 67$ and 93 for 


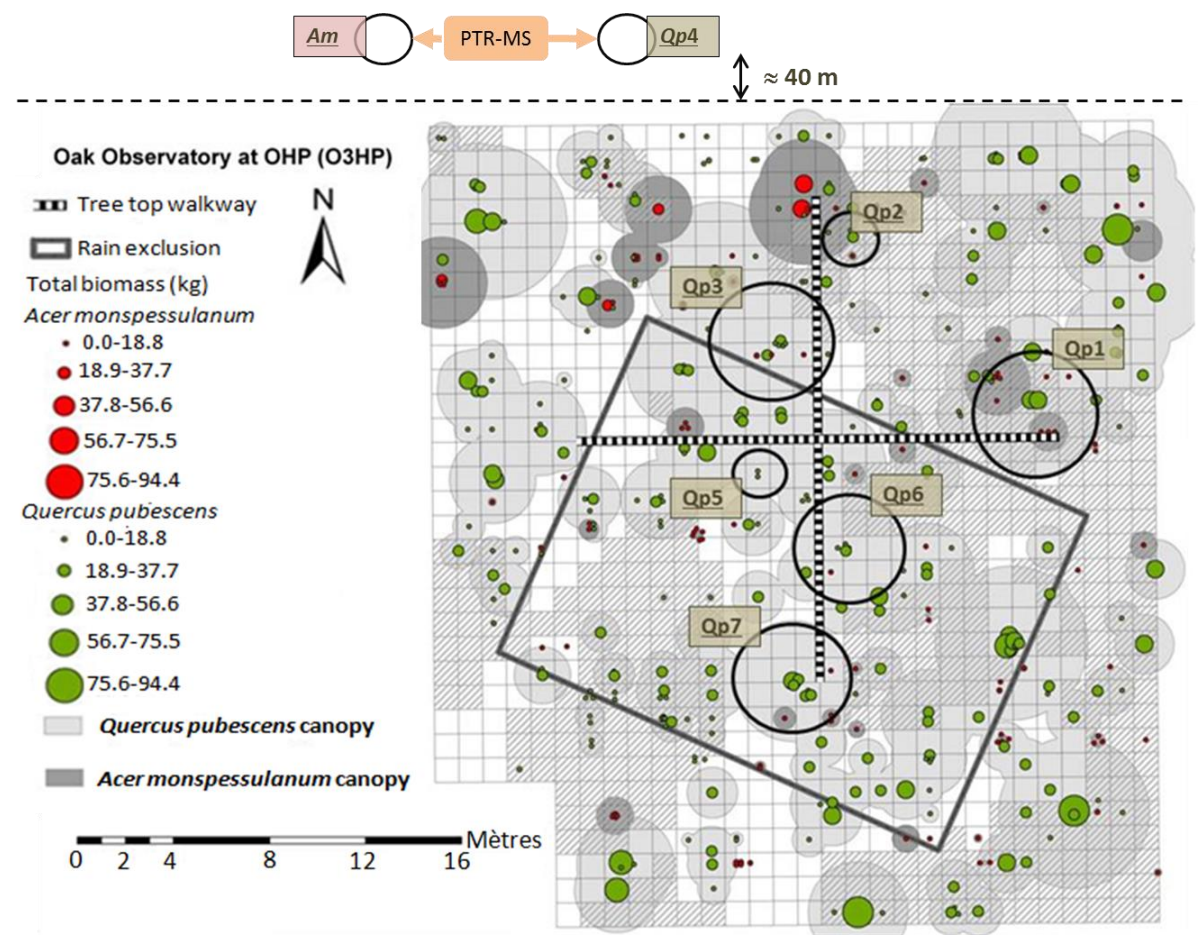

Figure 1. Location of the studied $i Q$. pubescens (Qpi) and Acer monspessulanum $(A m)$ trees. Branches $Q p 4$ and $A m$ were located $\approx 40 \mathrm{~m}$ north of the $\mathrm{O}_{3} \mathrm{HP}$ footbridge and BVOC emissions were measured using an online PTR-MS. All other $Q p$ i branches were sampled from the $\mathrm{O}_{3} \mathrm{HP}$ footbridge using adsorbent cartridges. Black circles in the $\mathrm{O}_{3} \mathrm{HP}$ area represent the assessed crown area of the sampled trees.

isoprene and monoterpene respectively. Daily whole range calibrations were carried out.

Laboratory intercomparison between IMBE and LSCE analytical GC-MS system was carried out by loading IMBE and LSCE isoprene standards in both types of tubes (glass and SS) over a $12-1400 \mathrm{ngC}$ range. A coefficient of determination $R^{2}$ of $0.953(n=14)$ and $1.000(n=7)$ for the GC-MSD HP 5973 and the GC-MSD Saturn 2200 respectively was found, with an estimation bias ranging from 3 to $10 \%$, close to the analytical precisions. Likewise, no significant differences were found between isoprene in situ samples $(0-150$ ngC $)$ simultaneously collected into glass and SS cartridges on either the inflowing or outflowing air of the enclosures $\left(n=20\right.$; slope $\left.=1.05 ; R^{2}=0.90\right)$. No breakthroughs were observed for isoprene, either on laboratory tests (up to $1400 \mathrm{ngC}$ ) or on in situ samples (up to $660 \mathrm{ngC}$ ) for both cartridges. No intercomparison was carried out for monoterpene analysis.

The overall uncertainty associated with emission rate measurements (including sampling and analytical uncertainties) for both sets of cartridges was between 15 and $20 \%$.

Details on VOC determination using the PTR-MS can be found in Kalogridis et al. (2014). Twelve masses were followed for both the Acer and the Quercus branch. Measurements of the inflowing and outflowing air were made al- ternatively every $15 \mathrm{~min}$, allowing an ER assessment every $30 \mathrm{~min}$.

\subsection{Statistics}

All statistics were performed on STATGRAPHICS ${ }^{\circledR}$ centurion XV by Statpoint, Inc. To compare the relationship between BVOCs emitted by $A$. monspessulanum and $Q$. pubescens branches studied with PTR-MS and the $C_{\mathrm{L}} \times C_{\mathrm{T}}$ factor, we performed a linear regression analyses. In order to check the absence of water stress impact on isoprene emission, slopes of the regression lines between ER and $C_{\mathrm{L}} \times C_{\mathrm{T}}$ in the control and rain-excluded plots were compared using an ANOVA. The same test was used to compare differences between sunlit and shaded branch emissions by comparing slopes of the regression lines between ER and $C_{\mathrm{L}} \times C_{\mathrm{T}}$ for this modality. Moreover differences in Pn, Gw, and Sw between control and rain-excluded trees were analysed using the Mann-Whitney test $(W)$.

\section{Results and discussion}

\subsection{Experimental site conditions}

During the first half of the campaign, the weather was fairly unstable, with few showers or longer periods of rain, in particular on 12 June which was rainy most of the day, and 


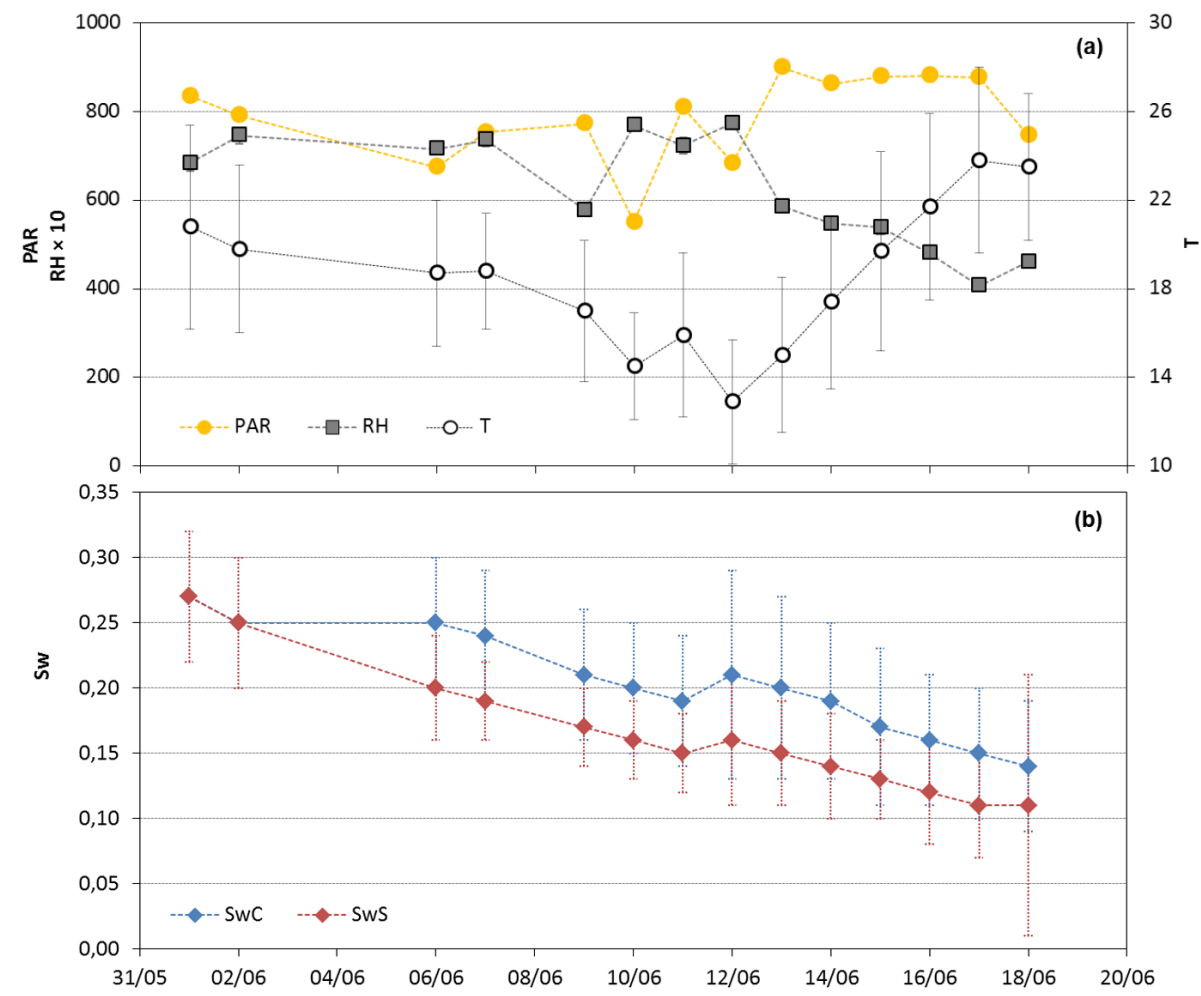

Figure 2. Environmental conditions prevailing at the $\mathrm{O}_{3} \mathrm{HP}$ site. (a) Daily mean photosynthetically active radiation PAR ( $\mu \mathrm{mol} \mathrm{m}^{-2} \mathrm{~s}^{-1}$ ), temperature $T\left({ }^{\circ} \mathrm{C}\right)$ and ambient relative humidity $\mathrm{RH}(\%)$ measured above canopy $(6.5 \mathrm{~m}$ above ground) and (b) soil water content $\mathrm{Sw}$ $\left(\mathrm{L}_{\mathrm{H}_{2} \mathrm{O}} \mathrm{L}_{\text {soil }}^{-1}\right)$ recorded in the control $(\mathrm{C}$, six different probes) and rain exclusion plots ( $\mathrm{S}$, five different probes) at $-0.1 \mathrm{~m}$.

an ambient temperature decreasing down to a mean daily value of about $13^{\circ} \mathrm{C}$. From 13 June and until the end of the measurements, the weather became more stable, sunnier, warmer and dryer; the daily mean air temperature increased constantly up to nearly $24^{\circ} \mathrm{C}$ by the end of the campaign, the ambient relative humidity decreased down to $40 \%$, and $\mathrm{Sw}$ in both plots decreased down to 0.11 and $0.15 \mathrm{~L}_{\mathrm{H}_{2} \mathrm{O}} \mathrm{L}_{\text {soil }}^{-1}$ for the rain exclusion and control plot respectively. From 6 June, $\mathrm{Sw}$ in the rain exclusion plot was systematically lower than in the control plot (Fig. 2b). Indeed, the annual cumulative precipitation in 2012 in the rain exclusion plot (data not shown) became significantly different since the beginning of May and was around 30\% lower compared to the control plot (comparison of means, Mann-Whitney test, $W=508.0$, $P<0.05)$.

\subsection{BVOC emission screening in the $\mathrm{O}_{3} \mathrm{HP}$ forest}

\subsubsection{Q. pubescens BVOC emissions}

BVOC emissions from $Q$. pubescens (obtained by PTRMS; $Q p 4$, Table 1) were consistent with previous literature results (Owen et al., 1998; Simon et al., 2005). Indeed, $Q$. pubescens was found to be a strong isoprene emitter, with a daily mean value of isoprene emission rate $\left(\mathrm{ER}_{\mathrm{iso}}\right)$ of $98 \mu \mathrm{gC} \mathrm{g}_{\mathrm{DM}}^{-1} \mathrm{~h}^{-1}$ representing, on average, $98.8 \%$ of the carbon emitted by the $Q p 4$ branch. The remaining $1.2 \%$ was found to represent a negligible quantity of the carbon assimilated as $\mathrm{CO}_{2}$ and was, in decreasing order, composed by methanol, total monoterpenes, acetone (altogether $\approx 84 \%$ of the non-isoprene BVOCs), methyl-vinyl-ketone $(\mathrm{MVK})+$ methacrolein (MACR) and acetaldehyde, whose emissions were of the order of $0.1 \mu \mathrm{gC} \mathrm{g}_{\mathrm{DM}}^{-1} \mathrm{~h}^{-1}$. Since isoprene and total monoterpene emissions have been observed to be light and temperature dependent in this study, $Q$. pubescens emission factors (EF) could be assessed using the G93 algorithm (Guenther et al., 1993) and are presented in Table 1 for $Q p 4$.

Methanol is thought to be produced by destruction of wall cells during growth or during leaf senescence (Galbally and Kirstine, 2002). It could be both a non-stored or stored compound in the water compartments of the cell, such as vacuoles. However, since $Q p 4$ methanol emissions were mainly exponentially dependent on temperature $\left(R^{2}=0.9, P<0.001\right)$ as previously observed for Picea species (Hayward et al., 2004) and lemon trees (Fares et al., 2011), it is likely that $Q$. pubescens methanol emissions come from an internal pool as suggested by Seco et al. (2007). In the afternoon, methanol emissions became the main non-isoprene compound emitted by $Q$. pubescens. 
Table 1. BVOCs emitted by $Q$. pubescens ( $Q p 4)$ and $A$. monspessulanum $(A m)$ branches, 1 and 2 June respectively, measured with a PTRMS. Daily mean $(n=30)$ and maximum (parenthesis) BVOC branch emission rates (ERs) are in $\mu \mathrm{gCg}_{\mathrm{DM}}^{-1} \mathrm{~h}^{-1}$. Values are expressed \pm their SD.

\begin{tabular}{|c|c|c|c|c|c|c|c|c|c|c|}
\hline \multirow{3}{*}{$\begin{array}{l}\text { Compound } \\
\text { Methanol }\end{array}$} & \multicolumn{5}{|c|}{$\begin{array}{c}Q p 4 \\
(\mathrm{PAR}=851.7 ; T=28.7 \pm 4.9 ; \mathrm{RH}=68.7 \pm 10.3 ; \mathrm{Pn}=8.3 \pm 2.8 ; \mathrm{GW}=189.6 \pm 157.6)^{\mathrm{a}}\end{array}$} & \multicolumn{5}{|c|}{$\begin{array}{c}A m \\
(\mathrm{PAR}=460.9 ; T=26.6 \pm 4.4 ; \mathrm{RH}=75.2 \pm 18.7 ; \mathrm{Pn}=2.3 \pm 1,3 ; \mathrm{Gw}=85.3 \pm 45.9)^{\mathrm{a}}\end{array}$} \\
\hline & \multicolumn{2}{|l|}{ ER } & \multicolumn{2}{|c|}{ Relative composition $^{\mathrm{b}}$} & \multirow{2}{*}{$\begin{array}{r}\mathrm{EF}^{\mathrm{c}} \\
0.50 \pm 0.04\end{array}$} & \multicolumn{2}{|l|}{ ER } & \multicolumn{2}{|c|}{ Relative composition ${ }^{b}$} & \multirow{2}{*}{$\frac{\mathrm{EF}^{\mathrm{c}}}{0.39 \pm 0.04}$} \\
\hline & $0.49 \pm 0.10$ & $(0.98)$ & 0.5 & $\{41.5\}$ & & $0.23 \pm 0.08$ & $(0.57)$ & 26.7 & $\{43.4\}$ & \\
\hline Acetaldehyde & $0.09 \pm 0.03$ & $(0.30)$ & 0.1 & $\{7.6\}$ & $0.12 \pm 0.01$ & $0.13 \pm 0.06$ & $(0.38)$ & 15.1 & $\{24.5\}$ & $0.28 \pm 0.03$ \\
\hline Acetone & $0.20 \pm 0.06$ & $(0.46)$ & 0.2 & $\{16.9\}$ & $0.27 \pm 0.02$ & $0.14 \pm 0.04$ & $(0.32)$ & 16.3 & $\{26.4\}$ & $0.24 \pm 0.02$ \\
\hline Isoprene & $98 \pm 31$ & (229) & 98.8 & - & $138 \pm 10$ & $0.33 \pm 0.09$ & $(0.73)$ & 38.4 & - & $0.47 \pm 0.04$ \\
\hline MVK + MACR & $0.10 \pm 0.03$ & $(0.26)$ & 0.1 & $\{8.5\}$ & $0.15 \pm 0.01$ & $0.01 \pm 0.005$ & $(0.04)$ & 1.2 & $\{1.9\}$ & $0.030 \pm 0.002$ \\
\hline Monoterpenes $^{\mathrm{d}}$ & $0.30 \pm 0.10$ & $(0.77)$ & 0.3 & $\{25.4\}$ & $0.44 \pm 0.03$ & $0.02 \pm 0.01$ & $(0.07)$ & 2.3 & $\{3.8\}$ & $0.050 \pm 0.003$ \\
\hline
\end{tabular}

Since methanol release, as other alcohols, is strongly stomatal dependent, its maximum relative contribution to the emitted carbon was observed at dawn: up to $6.9 \%$ of the carbon emitted as BVOC (data not shown) compared to 3.1 and $0.8 \%$ later in the morning and in the afternoon respectively. Although no methanol emissions were previously reported for $Q$. pubescens, the mean emission rate measured of $0.49 \mu \mathrm{gC} \mathrm{g}_{\mathrm{DM}}^{-1} \mathrm{~h}^{-1}$ (or $130 \mathrm{ng} \mathrm{g}_{\mathrm{DM}}^{-1} \mathrm{~h}^{-1}$, or $1.13 \mathrm{nmol} \mathrm{m}^{-2} \mathrm{~s}^{-1}$ ) is in the medium range of the foliar emissions reviewed by Seco et al. (2007) for methanol emissions from emitters other than $Q$. Pubescens.

Total monoterpene emissions were more than 300 times lower than isoprene emissions, in agreement with a factor of 250 found by Simon et al. (2005) for $Q$. pubescens studied under Mediterranean conditions. Monoterpenes were found to be mainly under $\alpha$-pinene and limonene (67 and $33 \%$ respectively - data from cartridge samplings, not shown) and their emission rates were more light and temperature dependent ("de novo emissions") than only temperature dependent ("pool emission") $\left(R^{2}=0.87\right.$ and 0.64 respectively and $P<0.001)$.

As for methanol, no acetone emissions have been previously reported for $Q$. pubescens. The mean emission rate of $0.20 \mu \mathrm{gCg}_{\mathrm{DM}}^{-1} \mathrm{~h}^{-1}$ (or $320 \mathrm{ng} \mathrm{g}_{\mathrm{DM}}^{-1} \mathrm{~h}^{-1}$, or $0.15 \mathrm{nmol} \mathrm{m}^{-2} \mathrm{~s}^{-1}$ ) is also in the medium range of the foliar emissions reviewed by Seco et al. (2007). The relative contribution of acetone to the total BVOC emissions remained fairly stable throughout the whole day of measurement (around $12.5 \%$ of the non-isoprene BVOCs) and was found to be influenced by ambient light and temperature variations $\left(R^{2}=0.88\right.$ and $\left.P<0.001\right)$.

$\mathrm{MVK}+\mathrm{MACR}$ are mainly secondary products of isoprene oxidation (Jardine et al., 2012). Our study showed that MVK + MACR emission rates were highly $\left(R^{2}=\right.$ 0.97, $P<0.001, n=28$ ) correlated with $\mathrm{ER}_{\text {iso }}$ all throughout the diurnal cycle. A direct primary emissions of these compounds by the $Q$. pubescens branch could thus not be proven, and values presented in the Table 1 should be then considered as the upper limit for primary emissions from this emitter.

Similarly, if acetaldehyde detected in our enclosure were mostly from primary biogenic source (cell catabolism, see
Fall et al., 1999 and Loreto et al., 2006), the emission rates thus assessed $\left(0.09 \mu \mathrm{gC} \mathrm{g}_{\mathrm{DM}}^{-1} \mathrm{~h}^{-1}, 165 \mathrm{ng} \mathrm{g}_{\mathrm{DM}}^{-1} \mathrm{~h}^{-1}\right.$ or $0.10 \mathrm{nmol} \mathrm{m}^{-2} \mathrm{~s}^{-1}$ ) would be in the lower range of the foliar emission rates reported in the literature for other plants (Seco et al., 2007). As for methanol emissions, the relative contribution of acetaldehyde emissions to total assimilated carbon was observed to peak in the morning ( $1.5 \%$ compared to $0.06 \%$ in the afternoon).

\subsubsection{A. monspessulanum BVOC emissions}

A. monspessulanum total BVOC emissions $\left(<1 \mu \mathrm{gCg} \mathrm{g}_{\mathrm{DM}}^{-1} \mathrm{~h}^{-1}\right) \quad$ were 2 orders of magnitude smaller than the total $Q$. pubescens BVOC emissions (> $100 \mu \mathrm{gC} \mathrm{g}_{\mathrm{DM}}^{-1} \mathrm{~h}^{-1}$; Table 1). Isoprene and methanol were the two dominant BVOCs measured, with a daily mean emission rate of 0.33 and $0.23 \mu \mathrm{gC} \mathrm{g}_{\mathrm{DM}}^{-1} \mathrm{~h}^{-1}$ respectively. Acetone, acetaldehyde and total monoterpenes were measured at lower rates, the latter being close to our detection limit. No foliar BVOC emission values have been reported in the literature for A. monspessulanum. Nevertheless, our findings confirm that like other Acer species (such as Acer platanoides L., A. rubrum L., or A. saccharinum L., Kesselmeier and Staudt, 1999), A. monspessulanum is a weak isoprene or other BVOC emitter.

BVOCs other than isoprene represented a lower fraction of the total carbon emitted in the morning $(\approx 33 \%)$ than in the afternoon $(\approx 66 \%)$, with methanol emission rates, in the morning, even higher than isoprene emission rates. Total BVOC emissions represented less than $0.2 \%$ of the assimilated carbon.

Ambient light and temperature variations influenced the diurnal emission variations of all the measured BVOC except methanol which, as observed for $Q$. pubescens, was found to be exponentially dependent.

To conclude, $Q$. pubescens appeared to be the main BVOC emitter in the $\mathrm{O}_{3} \mathrm{HP}$ forest compared to A. monspessulanum. Isoprene represented $\approx 99 \%$ of the BVOC emitted by $Q$. pubescens, with daily mean values as high as $\approx 100 \mu \mathrm{gC} \mathrm{g}_{\mathrm{DM}}^{-1} \mathrm{~h}^{-1}$. Therefore, sections hereafter focus on $Q$. pubescens isoprene emissions. 


\subsection{Q. pubescens isoprene emissions and associated gas exchange at the canopy scale (tree-to-tree and within canopy)}

The additional drought imposed about 1 month before the beginning of the measurements in the rain exclusion plot was not intense enough to significantly alter either the capacity of $Q$. pubescens to assimilate $\mathrm{CO}_{2}$ or to emit isoprene (comparison of regression lines; $\left.R^{2}=0.63 ; P>0.05\right)$. Although significant differences were observed in $\mathrm{Gw}$ with a value for stressed trees half the one for control trees (Mann-Whitney; $P<0.001$, Table 2), isoprene emissions have been suggested to not be constrained by stomatal conductivity as pointed out by Niinemets and Reichstein (2003). Thus water stress was not considered in this study. As a result, trees growing in both the rain exclusion and the control plot were pooled and analysed together without regard to their control/drought status.

\subsubsection{Plant physiology}

Daily Pn and Gw measured for top canopy branches varied between 5.4 and $13.8 \mu \mathrm{mol} \mathrm{CO} \mathrm{m}^{-2} \mathrm{~s}^{-1}$ and 62.5 and $268.1 \mathrm{mmolH}_{2} \mathrm{O} \mathrm{m}^{-2} \mathrm{~s}^{-1}$ respectively (Table 2 ). These values are in agreement with observations previously reported by Damesin and Rambal (1995) for $Q$. pubescens in June (Pn of $10 \mu \mathrm{mol} \mathrm{m}^{-2} \mathrm{~s}^{-1}$ and Gw ranging from 50 to $150 \mathrm{mmolH}_{2} \mathrm{O} \mathrm{m}^{-2} \mathrm{~s}^{-1}$ ). Gw up to $450 \mathrm{mmol} \mathrm{H}_{2} \mathrm{O} \mathrm{m}^{-2} \mathrm{~s}^{-1}$ was reported for Quercus ilex L. in the Mediterranean climate (Acherar and Rambal, 1992). Thus, despite the inherent modifications occurring in the microclimate surrounding an enclosed branch (higher relative humidity - especially during the night-time respiration - and warmer air temperature), no significant impact on the physiology of the studied branches was observed. Similarly, the rain event of 12 June had no impact on Pn of $Q p 1$ or $Q p 6$ branches studied on this day. Shaded branches $Q p 1_{\text {shade }}$ and $Q p 2_{\text {shade }}$ showed Pn values between 2.8 and $6.4 \mu \mathrm{mol} \mathrm{CO} \mathrm{Cm}^{-2} \mathrm{~s}^{-1}$, less than half the values of sunlit branches.

\subsubsection{Canopy variability of the branch isoprene emission rate}

As shown in Table 2, daily mean isoprene emission rates $\left(E R_{d}\right)$ from top of the canopy branches were highly variable, fluctuating over 1 order of magnitude, between below 10 ( $Q p 1$ and $Q p 6,12$ June) and up to $98 \mu \mathrm{gC} \mathrm{g}_{\mathrm{DM}}^{-1} \mathrm{~h}^{-1}$ ( $Q p 4$, 1 June). The lower $\mathrm{ER}_{\mathrm{d}}$ coincided with reduced incident PAR and ambient temperature due to some rain events on 12 June. Since $Q p 4$ Pn was similar to Pn measured for the other trees (8.3 and between 5.4 and $13.8 \mu \mathrm{mol} \mathrm{CO}_{2} \mathrm{~m}^{-2} \mathrm{~s}^{-1}$ respectively), the observed $\mathrm{ER}_{\mathrm{d}}$ range illustrates the importance of environmental conditions on the amount of carbon Q. pubescens allocates to isoprene emissions.

Daily mean $\mathrm{ER}_{\mathrm{d}}$ presented a high variability between sunlit branches (23 and $98 \mu \mathrm{gC} \mathrm{g} \mathrm{DD}_{\mathrm{DM}}^{-1} \mathrm{~h}^{-1}$ ) and shaded

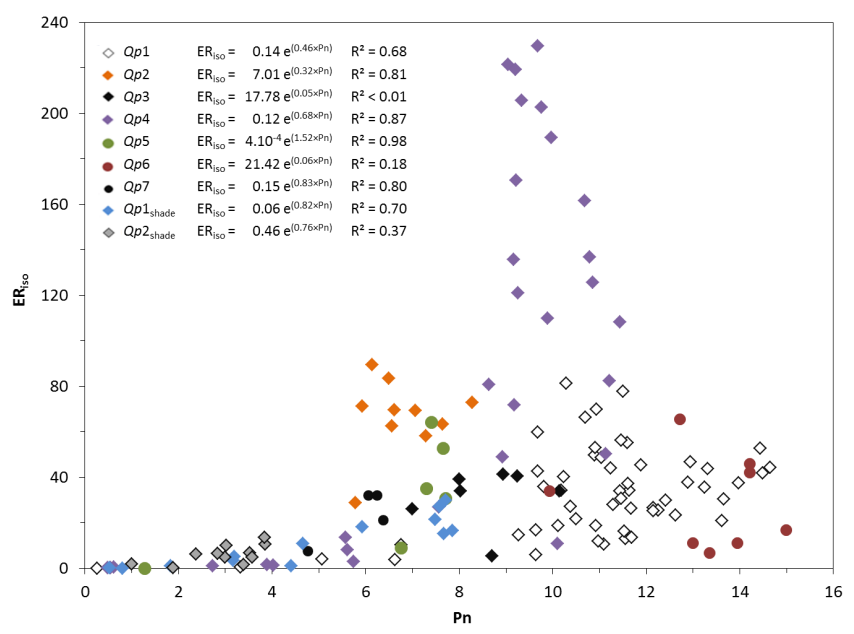

Figure 3. Isoprene emission rate $\mathrm{ER}_{\text {iso }}\left(\mu \mathrm{gC} \mathrm{g}_{\mathrm{DM}}^{-1} \mathrm{~h}^{-1}\right)$ vs. net photosynthetic assimilation $\mathrm{Pn}\left(\mu_{\mathrm{mol}} \mathrm{CO} 2 \mathrm{~m}^{-2} \mathrm{~s}^{-1}\right)$. Exponential dependency equation and determination coefficient $R^{2}$ are given for each $Q p$ i branch.

branches (4.0 and $13 \mu \mathrm{gC} \mathrm{g}_{\mathrm{DM}}^{-1} \mathrm{~h}^{-1}$ ). Daily mean $Q p 1_{\text {shade }}$ and $Q p 2_{\text {shade }}$ PAR were reduced by a factor of 6 and 10 respectively compared to PAR values recorded on $Q p 1$ and $Q p 2$ sunlit branches. Consequently, shaded $\mathrm{ER}_{\mathrm{d}}$ (between 4.0 and $13 \mu \mathrm{gC} \mathrm{g}_{\mathrm{DM}}^{-1} \mathrm{~h}^{-1}$ ) were, on average, between 2 and 10 times lower than the values measured on the sunlit $Q p 1$ and $Q p 2$ branches respectively; these values were the lowest $\mathrm{ER}_{\mathrm{d}}$ observed during the study. In shaded branches, only $0.3 \pm 0.2$ to $0.5 \pm 0.2 \%$ of the assimilated carbon was emitted as isoprene $\left(\mathrm{C}_{\mathrm{iso}}\right)$, while $\mathrm{C}_{\mathrm{iso}}$ for sunlit branches ranged between $0.4 \pm 0.1$ and $2.9 \pm 1.0 \%$. Daily mean $\mathrm{C}_{\text {iso }}$ was exceptionally high for $Q p 4(2.7 \pm 2.2 \%)$ and reached up to $6.5 \%$ at solar noon.

Whatever their horizontal or vertical location in the canopy, for two-thirds of the sampled trees, measured isoprene emission rates exponentially increased with Pn, except

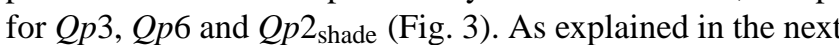
section, $Q p 3$ was found to be dead in August, although there were no visible signs when our study was conducted. $Q p 6$ was studied during the only rainy day of our study (12 June, Table 2), and although its Pn was not affected, its isoprene emissions were much lower than during sunny days. As the range of $\mathrm{ER}_{\text {iso }}$ variation observed for $Q p 2_{\text {shade }}$ was much lower than for other sunlit branches, it was difficult to distinguish an exponential dependency on Pn as strong as for the other branches. Aside from these particular cases, such an exponential relation between $\mathrm{ER}_{\text {iso }}$ and $\mathrm{Pn}$ implies that even when Pn reached the maxima values, the contribution of carbon fixed by each branch to produce isoprene went on increasing. 
Table 2. Environmental and physiological parameters recorded during isoprene measurements on seven sunlit (Qpi) and two shaded $\left(Q p i_{\text {shade }}\right) Q$. pubescens branches. PAR $\left(\mu \mathrm{mol} \mathrm{m}{ }^{-2} \mathrm{~s}^{-1}\right)$, temperature $T\left({ }^{\circ} \mathrm{C}\right)$, relative humidity RH $(\%)$, photosynthetic net assimilation $\mathrm{Pn}\left(\mu \mathrm{mol} \mathrm{CO} \mathrm{m}^{-2} \mathrm{~s}^{-1}\right)$ and stomatal conductance $\mathrm{Gw}\left(\mathrm{mmolH}_{2} \mathrm{O} \mathrm{m}^{-2} \mathrm{~s}^{-1}\right)$ were recorded inside the enclosure and averaged over 02:0022:00. Daily emission rates $\mathrm{ER}_{\mathrm{d}}\left(\mu \mathrm{gC} \mathrm{g} \mathrm{DM}^{-1} \mathrm{~h}^{-1}\right)$ were averaged over the $n$ isoprene measurements of the sampled branch; values in brackets are minimum-maximum. Assimilated carbon emitted as isoprene $\mathrm{C}_{\mathrm{iso}}(\%)$ is given $\pm \mathrm{SD}$. For every branch, isoprene emission rates $\mathrm{ER}_{b r}$ and emission factor Is (as in Guenther et al. 1993) $\pm \mathrm{SD}$ are given in $\mu \mathrm{gC} \mathrm{g}_{\mathrm{DM}}^{-1} \mathrm{~h}^{-1}$ and $\mathrm{ngC} \mathrm{m}^{-2} \mathrm{~h}^{-1}$ (in parentheses).

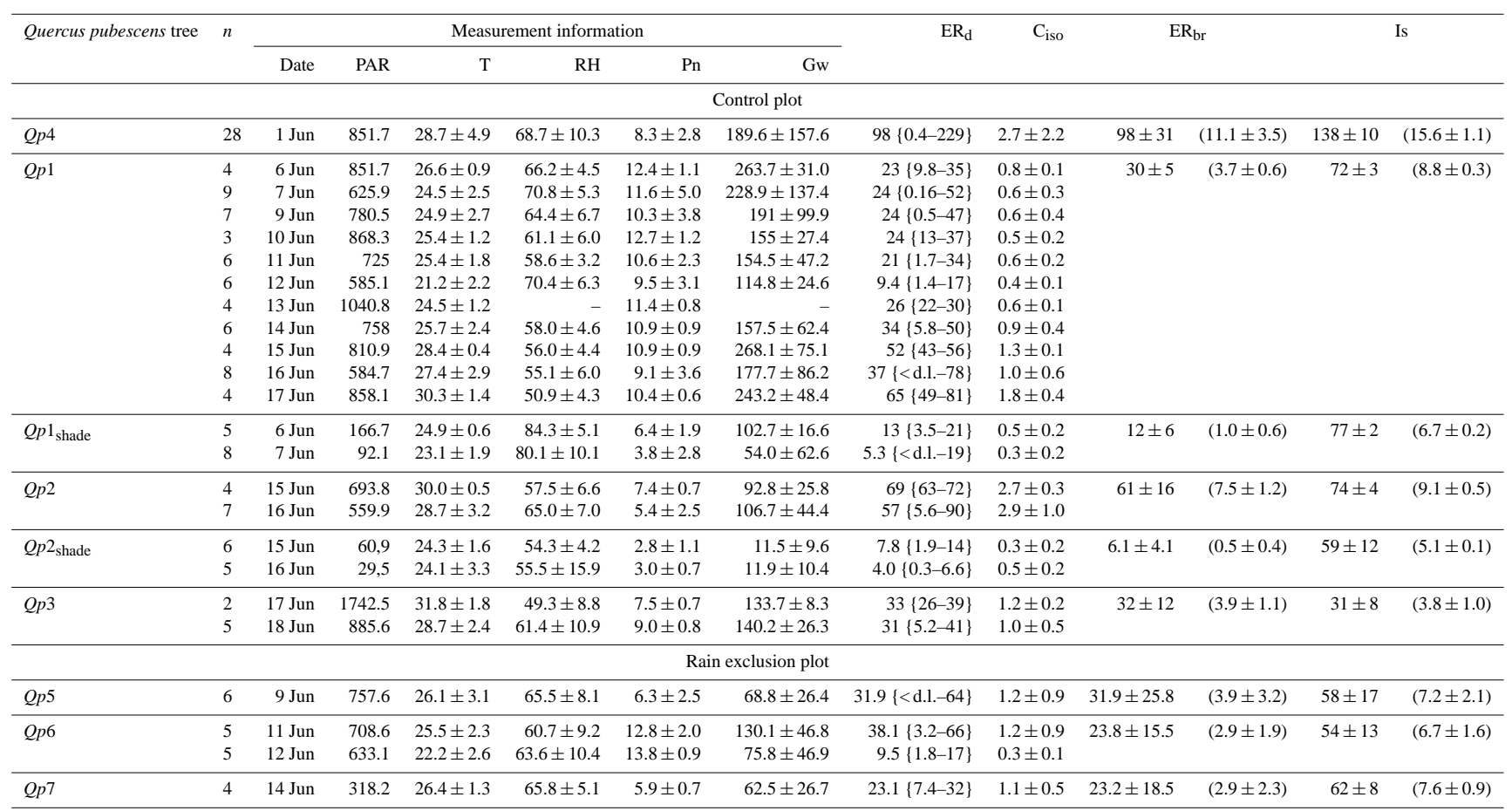

\subsubsection{Capturing $Q$. pubescens isoprene emission variability and providing estimates}

\subsubsection{Canopy variability of the isoprene emission factor Is}

As isoprene emissions are known to strongly depend on temperature and PAR variations, the slope of measured isoprene emission rates vs. the $C_{\mathrm{L}} \times C_{\mathrm{T}}$ product was calculated in order to assess an emission factor Is for each branch (Table 2), where $C_{\mathrm{L}}$ and $C_{\mathrm{T}}$ are light and temperature dimensionless coefficients given by Guenther et al. (1993) from experimental measurements (see Appendix A). For sunlit branches, Is varied between $31 \pm 8$ and $138 \pm 10 \mu \mathrm{gC} \mathrm{g}_{\mathrm{DM}}^{-1} \mathrm{~h}^{-1}$ for $Q p 3$ and $Q p 4$ respectively, which is in the range of values given in the literature $\left(50,66\right.$ and $118 \mu \mathrm{gC} \mathrm{g}_{\mathrm{DM}}^{-1} \mathrm{~h}^{-1}$, Kesselmeier et al. (1998), Owen et al. (1998) and Simon et al. (2005) respectively). A factor of more than 2 was found, on the one hand, between $Q p 4$ emission factor and all the other branches in the control plot, and, on the other hand, between Is from $Q p 1$ and $Q p 2$ ( $72 \pm 3$ and $74 \pm 4 \mu \mathrm{gC} \mathrm{g}_{\mathrm{DM}}^{-1} \mathrm{~h}^{-1}$ respectively) and Qp3 $\left(31 \pm 8 \mu \mathrm{gC} \mathrm{g}_{\mathrm{DM}}^{-1} \mathrm{~h}^{-1}\right)$. The overall factor of variability of 4.3 observed in Is illustrates how in situ condition variations, even on a fairly homogenous site, can impact BVOC emissions. Moreover, even under similar prevailing environmental conditions, the physiological status variability that may exist between branches can lead to strong differences in the branch capacity to emit isoprene. The smaller (by a factor of 2) Is observed for $Q p 3$ compared to other $\mathrm{O}_{3} \mathrm{HP}$ tree branches was a posteriori explained by the fact that this branch died in August despite no injuries were visible during our study in June. By contrast Steinbrecher et al. (2013) observed a remarkable stability of Is values from seedlings of various oak species originating from different environmental climates (precipitation, temperature) with a factor of only 1.6 for $Q$. pubescens Is.

Regarding the canopy shading effect, the studied shaded branches showed no significant difference $\left(R^{2}=72.8\right.$ and 89.2 for $Q p 1$ and $Q p 2$ branches respectively; $P>0.05$ ) in their capacity to emit isoprene (Is of $77 \pm 3$ and $59 \pm 12 \mu \mathrm{gCg} \mathrm{g}_{\mathrm{DM}}^{-1} \mathrm{~h}^{-1}$ for $Q p 1_{\text {shade }}$ and $Q p 2_{\text {shade }}$ respectively) compared to the sunlit branch of the corresponding tree (Is of $72 \pm 3$ and $74 \pm 4 \mu \mathrm{gC} \mathrm{g}-1 \mathrm{D}^{-1}$ for $Q p 1$ and $Q p 2$ respectively). This similarity occurred despite an observed LMA vertical gradient: $87 \pm 2$ and $123 \pm 1 \mathrm{~g} \mathrm{~m}^{-2}$ for shaded and sunlit branches respectively. Such a gradient is similar to what Harley et al. (1994) reported for a Quercus alba forest: $75.4 \pm 7.0$ and $111.5 \pm 5.9 \mathrm{~g} \mathrm{~m}^{-2}$ for shaded and sunlit 
branch respectively; when these authors expressed Is on a leaf area basis they observed significantly lower Is values for a shaded branch. Note that if the sunlit branch LMA value were used for assessing Is from all our branches (shaded and sunlit branches) - as it may be done in global upscaling inventory when no appropriate LMA information is available shaded Is value would then become significantly lower than Is sunlit branches. As any other factors used when BVOC canopy fluxes are extrapolated from branch to canopy scale, the determination of appropriate LMA should thus be as accurate as possible since it represents one of the biases of such an exercise.

Based on our assessed Is range ( 31 to $138 \mu \mathrm{gC} \mathrm{g}_{\mathrm{DM}}^{-1} \mathrm{~h}^{-1}$ ) and using an average branch-scale Is value of $60 \mu g \mathrm{Cg}_{\mathrm{DM}}^{-1} \mathrm{~h}^{-1}$, Kalogridis et al. (2014) extrapolated a canopy isoprene emission flux of $15 \mathrm{mg} \mathrm{m}^{-2} \mathrm{~h}^{-1}$, twice the mean canopy flux measured in June during this study by the disjunct eddy covariance technique $\left(6.6 \mathrm{mg} \mathrm{m}^{-2} \mathrm{~h}^{-1}\right)$. The authors pointed out that such a factor of discrepancy is reasonable since it is in the range of uncertainties typically obtained for upscaling exercises (see for example Guenther et al., 1995), and is within the range of the tree-to-tree variability observed for $Q$. pubescens Is at this site (a factor of 4.3). How much the Is canopy variability is extensively and intensively studied illustrates the limit of precision in BVOC canopy flux assessments.

\subsubsection{Diurnal variability: how well did $C_{\mathrm{L}} \times C_{\mathrm{T}}$ capture the observed features?}

The diurnal range of isoprene ER variations observed over the seven sunlit different branches studied (Fig. 4a) was found to fluctuate from day to day and with environmental conditions (Fig. 4b). The maximum value observed on June 12 (rainy day) for the sun-exposed $Q p 1$ branch $\left(17 \mu g \mathrm{gg}_{\mathrm{DM}}^{-1} \mathrm{~h}^{-1}\right)$ was about 5 times lower than the maximum observed at the end of the campaign (especially on 16 June, $78 \mu \mathrm{gC} \mathrm{g}_{\mathrm{DM}}^{-1} \mathrm{~h}^{-1}$ ), when weather was much warmer and sunnier (Table 2 and Fig. 4b); it was about the same as the maximum ER measured for the shaded branch $Q p 1$ at the beginning of the campaign (6-7 June, $\approx 20 \mu \mathrm{gCg}_{\mathrm{DM}}^{-1} \mathrm{~h}^{-1}$ ). $Q p 1 \mathrm{C}_{\text {iso }}$ was the highest (up to $1.8 \%$, Table 2) at the end of the campaign, compared to values $<1 \%$ at the beginning of our measurements, which is consistent with previous findings for $Q$. pubescens in June (0.62 to $1.8 \%$, Kesselmeier et al., 1998).

Diurnal variations were studied in more detail during the Qp4 high frequency measurements carried out with the PTRMS system. Positive Pn values were measured at 06:30 LT as soon as PAR became detectible and increased at dawn in parallel of a $C_{\mathrm{L}}$ increase (Fig. 5). Detectable isoprene emissions were observed only $2 \mathrm{~h}$ later (08:30), when ambient temperature significantly increased (Fig. 5). Consequently, isoprene ER increased then as $C_{\mathrm{T}}$. This finding contrasts with previous studies (Owen et al., 1998) where $Q$. pubescens ERs were more PAR dependent than temperature dependent. The morning delay observed between Pn and the isoprene emissions onset was found to correspond to a temperature increase $\mathrm{d} T$ of nearly $3^{\circ} \mathrm{C}$; interestingly, a similar $\mathrm{d} T$ was observed for the $Q p 1$ branch when early morning measurements were made. Temperature continued to significantly (compared to PAR) impact isoprene until the maximum ER $\left(229 \mu \mathrm{gC} \mathrm{g}_{\mathrm{DM}}^{-1} \mathrm{~h}^{-1}\right.$ at 13:30). Between 13:30 and 17:30 isoprene emissions remained constantly more temperature dependent than light dependent. As soon as PAR decreased (17:30), ER started to decrease to non-detectable values, while the branch continued to assimilate $\mathrm{CO}_{2}$ and $\mathrm{Pn}$ decreased only $1 \mathrm{~h}$ later. If the diurnal variations of $Q p 4 \mathrm{ERs}$ were mostly well described by $C_{\mathrm{L}} \times C_{\mathrm{T}}$ (in particular the maximum from dawn to midday and during the evening), the relative influence of light and temperature varied throughout the day as presented in Fig. 6: from 13:30 to 16:00 ER decreased from 220 to less than $150 \mu \mathrm{gC} \mathrm{g}_{\mathrm{DM}}^{-1} \mathrm{~h}^{-1}$ at nearly constant $C_{\mathrm{L}} \times C_{\mathrm{T}}$; on the contrary, after 16:00, ER remained close to $75 \mu \mathrm{gCg}_{\mathrm{DM}}^{-1} \mathrm{~h}^{-1}$ although $C_{\mathrm{L}} \times C_{\mathrm{T}}$ fluctuated by nearly a factor of 3 (from 1.1 to 0.4 ). Thus, after the solar noon, ER presented an overall reverse sigmoid shape diurnal dependency with $C_{\mathrm{L}} \times C_{\mathrm{T}}$. The sudden decrease of ER at 13:30 while $C_{\mathrm{L}} \times C_{\mathrm{T}}$ remained constant may illustrate a possible temperature midday stress of the branch, with emissions falling to a minimum value of $\approx 75 \mu \mathrm{gC} \mathrm{g}-1 \mathrm{~h}^{-1}$. The thermal stress lasted until 16:00 when isoprene emission regulation became again well correlated to $C_{\mathrm{L}} \times C_{\mathrm{T}}$. Indeed, as reported by Niinemets et al. (2010a) heat stress could modify isoprene emissions by decreasing foliar metabolism. For instance, Funk et al. (2004) observed that during heat stress, an alternative source of carbon (carbon pool stored as carbohydrates) is used for isoprene synthesis. As showed by Fortunati et al. (2008) for Populus nigra L., as this alternative carbon source is unaffected by temperature, our observations could illustrate a similar uncoupling between isoprene emissions and $C_{\mathrm{L}} \times C_{\mathrm{T}}$ for $Q$. pubescens. Note that such a response was also observed during water stress on Quercus species by Tani et al. (2011), who suggested that when photosynthesis was completely suppressed in the afternoon due to severe water stress, the DMAPP content (or dimethylallyl pyrophosphate, the substrate for isoprene synthase) was not high enough to maintain isoprene emission levels as before stress.

\subsubsection{Assessment of the diurnal profiles of $Q$. pubescens isoprene emission rates using different algorithms}

Most of the different isoprene emission algorithms available for emission inventory are based on the empirical leaflevel isoprene emission dependency on light and temperature (Guenther et al., 1993). Among them, two were tested to evaluate their ability in assessing the diurnal profiles of $Q$. pubescens isoprene emissions observed in this Mediterranean climate: $(i)$ the simple and well-known G93 algo- 


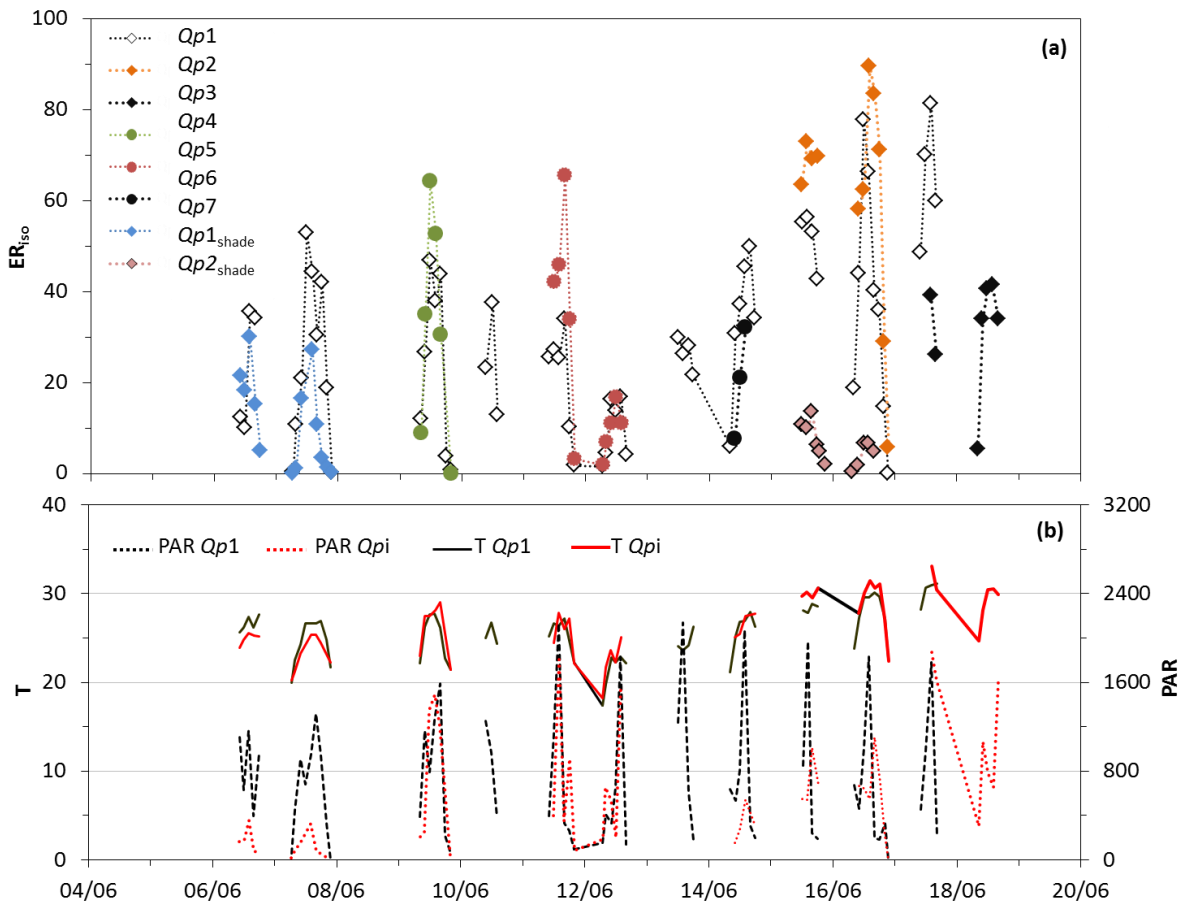

Figure 4. (a) Diurnal variations of isoprene emission rate $\mathrm{ER}_{\mathrm{iso}}\left(\mu \mathrm{gC} \mathrm{g}_{\mathrm{DM}}^{-1} \mathrm{~h}^{-1}\right)$ measured from all $i$ Qpi branches sampled on the $\mathrm{O}_{3} \mathrm{HP}$ footbridge with (b) corresponding PAR $\left(\mu \mathrm{mol} \mathrm{m} \mathrm{m}^{-2} \mathrm{~s}^{-1}\right)$ and temperature $T\left({ }^{\circ} \mathrm{C}\right)$ conditions.

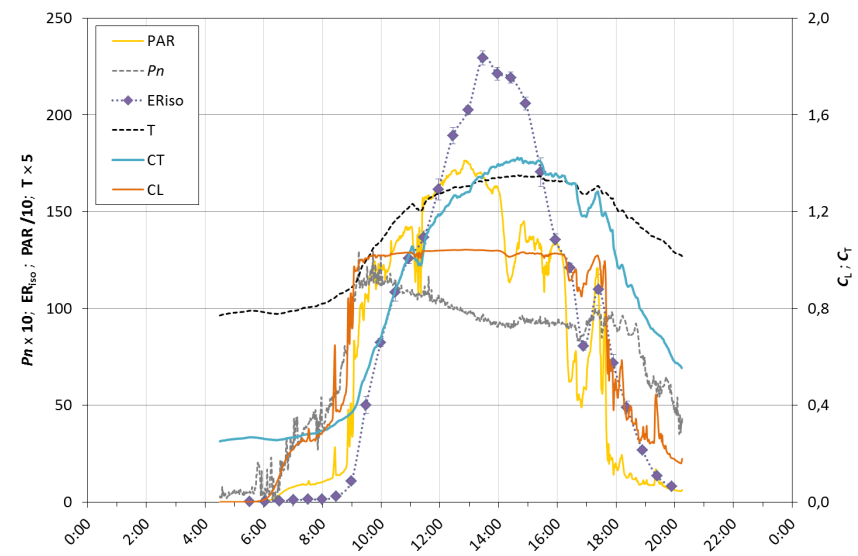

Figure 5. Diurnal variations of $Q p 4$ isoprene emission rates $\mathrm{ER}_{\mathrm{iso}}$ $\left(\mu \mathrm{gCg} \mathrm{g}_{\mathrm{DM}}^{-1} \mathrm{~h}^{-1}\right) \pm \mathrm{SD}$ vs. the corresponding net photosynthetic assimilation Pn $\left(\mu \mathrm{mol} \mathrm{CO} \mathrm{m}^{-2} \mathrm{~s}^{-1}\right)$, PAR $\left(\mu \mathrm{mol} \mathrm{m} \mathrm{m}^{-2} \mathrm{~s}^{-1}\right)$, temperature $T\left({ }^{\circ} \mathrm{C}\right)$ and $C_{\mathrm{L}}$ and $C_{\mathrm{T}}$ parameters (as in Guenther et al., 1993).

rithm (Guenther et al., 1993) which only takes into account the instantaneous variations of incident light and ambient temperature - hereafter referred to as G93 and (ii) the MEGAN (Model of Emissions of Gases and Aerosols from Nature) parameterisation (Guenther et al., 2006), a modified version of the former algorithm developed in an attempt to better capture the emission seasonality through the consid-

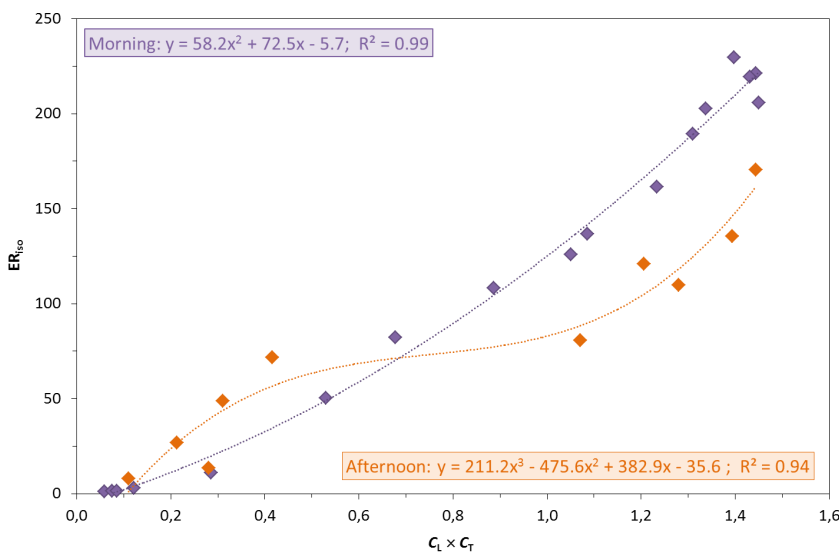

Figure 6. Diurnal variation of $Q p 4$ isoprene emission rate $\mathrm{ER}_{\text {iso }}$ $\left(\mu \mathrm{gCg} \mathrm{g}_{\mathrm{DM}}^{-1} \mathrm{~h}^{-1}\right)$ vs. $C_{\mathrm{L}} \times C_{\mathrm{T}}$ as in Guenther et al. (1993) (1 June). Purple diamonds are measurements between 08:00 and 14:00; orange diamonds are measurements between 14:30 and 20:00. Polynomial best fit equation and determination coefficient $R^{2}$ are given for morning (purple) and afternoon (orange).

eration of the dimensionless $\gamma_{\text {age }}$ factor dependent on leaf age (here set at 0.6), the lower frequency variations (up to 10 days) of environmental conditions and the impact of soil humidity through the $\gamma_{\mathrm{SM}}$ factor. The algorithms were tested for $Q p 4$ branch using both an Is value of $53 \mu \mathrm{gC} \mathrm{g}_{\mathrm{DM}}^{-1} \mathrm{~h}^{-1}$ as recommended by Simpson et al. (1999) for European 
Q. pubescens and our values obtained in this study (72 and $138 \mu \mathrm{gC} \mathrm{g}_{\mathrm{DM}}^{-1} \mathrm{~h}^{-1}$ for $Q p 1$ and $Q p 4$ respectively).

As a whole, both algorithms underestimated the ER measured from $Q p 4$ (65 and $55 \%$ for G93 and MEGAN respectively, Fig. 7, Table 3) when the Simpson et al. (1999) Is value was used. This discrepancy reached a factor of 3 for midday maximum emissions (74 and $93 \mu \mathrm{gCg} \mathrm{g}_{\mathrm{DM}}^{-1} \mathrm{~h}^{-1}$ for $\mathrm{G} 93$ and MEGAN respectively compared to $229 \mu \mathrm{gC} \mathrm{g}_{\mathrm{DM}}^{-1} \mathrm{~h}^{-1}$ ). When Is values observed during this study were employed, a much better agreement was found (a slight over- and underestimation of 16 and $8 \%$, and a root mean square error (RMSE) value $\approx 2$ and 3 times lower for G93 and MEGAN respectively, Fig. 7, Table 3). The main bias was thus found to be linked with Is since the general diurnal trend was roughly captured by both algorithms ( $R^{2}>0.91$ for all comparisons). However, note that the maximum $Q p 4$ emissions calculated with both algorithms were reached at 14:00 (MEGAN) and 15:30 (G93), later than what was observed (13:30) and regardless the Is value used. Besides, predicted ER remained mostly constant until 16:00, while the observed emissions decreased to ER values $50 \%$ smaller than the midday maximum as previously described and discussed (Sect. 3.4.2). As both algorithms are strongly dependant on temperature variations, such an observed uncoupling between ER and elevated temperature (here higher than $33^{\circ} \mathrm{C}$ ) could not be captured. ER evening decrease was predicted to occur more rapidly and earlier (18:00) compared to in situ observations, resulting in an estimated ER of $\approx 10 \mu \mathrm{gC} \mathrm{g} \mathrm{DM}_{\mathrm{DM}}^{-1} \mathrm{~h}^{-1}$ compared to the observed value of $75 \mu \mathrm{gCg} \mathrm{g}_{\mathrm{DM}}^{-1} \mathrm{~h}^{-1}$. On the contrary ER was assessed to occur much earlier at dawn (06:30 compared to 08:00), thus as soon as Pn became positive and was overestimated by a factor of 3 by G93 over this period. Note that for $Q p 4$, the simpler $\mathrm{G} 93$ algorithm performed almost as well as the more complex MEGAN parameterisation (similar slope, $R^{2}$ and RMSE, Table 3).

Some similar findings were observed when G93 and MEGAN algorithms were tested over the longer time series (13 days) of $Q p 1$ diurnal measurements: when the measured Is was employed instead of the literature value, the underestimation of G93 and MEGAN was reduced from 46 and $77 \%$ to 27 and $68 \%$ respectively, although RMSE remained in the same range (Table 3). However, MEGAN performance became much weaker $\left(R^{2}=0.15\right)$ for $Q p 1$, especially for the assessment of ER measured at the end of the 13-day period (detailed data not shown), when much warmer and drier conditions were established at the $\mathrm{O}_{3} \mathrm{HP}$ site. Indeed, the soil water content becoming lower than the wilting point used for our soil type $\left(0.138 \mathrm{~m}^{3} \mathrm{~m}^{-3}\right.$ for clay, Chen and Dudhia, 2001), the MEGAN $\gamma_{\text {SM }}$ factor was no longer 1 but significantly lowered most of the assessed isoprene emissions. Unfortunately, the consideration of superficial $(-0.1 \mathrm{~m}$ depth) soil moisture does not take into account trees' ability to access deeper water sources. As weather was cooler and rainy at the beginning of the campaign, such a $\gamma_{\mathrm{SM}}$ modulation did

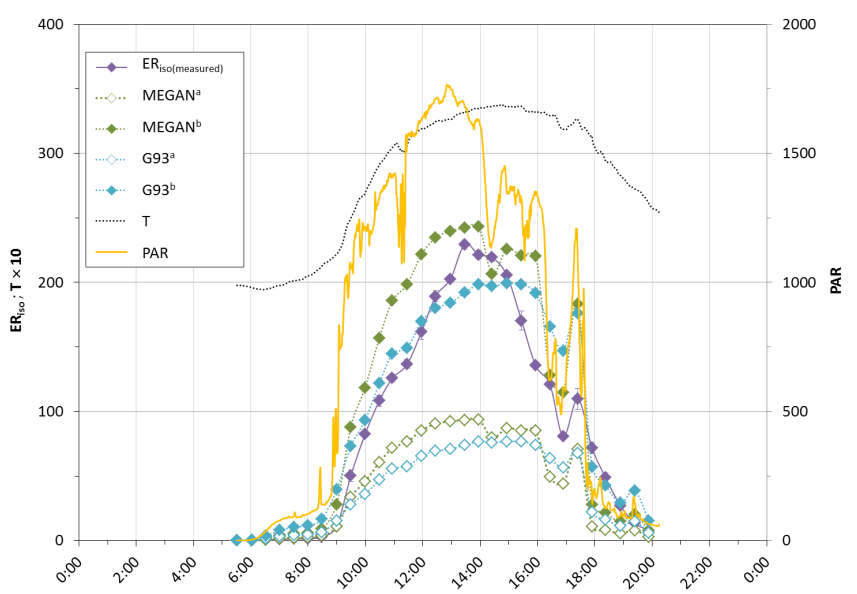

Figure 7. Comparison between $Q p 4$ isoprene emission rates $\mathrm{ER}_{\text {iso }}$ ( $\mu \mathrm{gC} \mathrm{g}_{\mathrm{DM}}^{-1} \mathrm{~h}^{-1} \pm \mathrm{SD}$ ) measured in situ (1 June, purple diamonds) and assessed using isoprene emission algorithm as in (i) Guenther et al. (1993) (G93, green diamonds) and as in (ii) MEGAN model (Guenther et al., 2006, blue diamonds) using a leaf age factor $\Upsilon_{\text {age }}$ of 0.6 and a soil water factor $\Upsilon_{\mathrm{SM}}$ of 1 . PAR $\left(\mu \mathrm{mol} \mathrm{m}{ }^{-2} \mathrm{~s}^{-1}\right)$ and temperature $T\left({ }^{\circ} \mathrm{C}\right)$ were recorded inside the enclosure. ${ }^{\text {a }}$ Emission factor Is value is $53 \mu \mathrm{gC} \mathrm{g}_{\mathrm{DM}}^{-1} \mathrm{~h}^{-1}$ (as in Simpson et al., 1999, open diamonds). ${ }^{b}$ Emission factor Is value is $138 \mu \mathrm{gCg}_{\mathrm{DM}}^{-1} \mathrm{~h}^{-1}$ (this study, solid diamonds).

not operate either on $Q p 4$ measurements or on the first day of the $Q p 1$ measurements ( $\gamma_{\mathrm{SM}}$ was 1 ). When $\gamma_{\mathrm{SM}}$ was not considered anymore and set to 1 for all the $Q p 1$ measurements, MEGAN performed much better and assessed nearly $60 \%$ of the observed variability compared to $15 \%$. However, in this case, MEGAN only slightly reduced the overall $Q p 1$ underestimation $(\approx 60 \%)$ compared to the simpler G93 algorithm $(\approx 40 \%)$, as for $Q p 4$ tree.

\section{Conclusions}

The extensive study, at branch scale, of BVOC emissions from a Mediterranean forest ecosystem dominated by $Q$. pubescens revealed that unlike $Q$. pubescens, $C$. coggygria was a non-isoprene emitter (no other BVOCs were investigated) and A. monspessulanum was a weak BVOC emitter (daily mean total $<1 \mu \mathrm{gCg} \mathrm{g}_{\mathrm{DM}}^{-1} \mathrm{~h}^{-1}$ ) with isoprene $(36.3 \%$ ) and methanol $(25.3 \%)$ the two dominant emitted compounds $\left(\mathrm{ER}_{\mathrm{d}}\right.$, of 0.33 and $0.23 \mu \mathrm{gC} \mathrm{g} \mathrm{gM}_{\mathrm{DM}}^{-1} \mathrm{~h}^{-1}$ respectively); acetone, acetaldehyde and total monoterpenes were also measured at lower rates.

$Q$. pubescens was found to be a strong isoprene emitter $(\approx 99 \%$ of the BVOC carbon mass) with mean ER fluctuating between 23 and $98 \mu \mathrm{gC} \mathrm{g}_{\mathrm{DM}}^{-1} \mathrm{~h}^{-1}$ for sunlit branches and 6.1 and $11.5 \mu \mathrm{gC} \mathrm{g} \mathrm{g}_{\mathrm{DM}}^{-1} \mathrm{~h}^{-1}$ for canopy shaded branches; methanol $\left(\mathrm{ER}_{\mathrm{d}}=0.49 \mu \mathrm{gC} \mathrm{g} \mathrm{DM}^{-1} \mathrm{~h}^{-1} ; 0.5 \%\right.$ of total BVOC) and total monoterpenes $\left(\mathrm{ER}_{\mathrm{d}}=0.30 \mu \mathrm{gC} \mathrm{g} \mathrm{gM}^{-1} \mathrm{~h}^{-1} ; 0.3 \%\right.$ of 
Table 3. Results of the comparison between calculated vs. measured $Q$. pubescens isoprene emission rates using both the G93 and MEGAN algorithm. The $a x+b$ best fit equations are given, together with the determination coefficient $\left(R^{2}\right)$ and the root mean square error (RMSE).

\begin{tabular}{|c|c|c|c|c|c|c|c|}
\hline \multirow[t]{2}{*}{ Tree } & & \multicolumn{3}{|l|}{$\mathrm{Is}^{\mathrm{a}}$} & \multicolumn{3}{|l|}{$\mathrm{Is}^{\mathrm{b}}$} \\
\hline & & $a x+b$ & $R^{2}$ & RMSE & $a x+b$ & $R^{2}$ & RMSE \\
\hline \multirow[t]{2}{*}{$Q p 4$} & G93 & $0.35 x+6.96$ & 0.91 & 73.67 & $0.92 x+18.05$ & 0.91 & 26.59 \\
\hline & MEGAN & $0.45 x+2.66$ & 0.92 & 65.89 & $1.16 x+6.90$ & 0.92 & 36.69 \\
\hline \multirow[t]{2}{*}{$Q p 1$} & G93 & $0.54 x+10.08$ & 0.74 & 11.88 & $0.73 x+13.61$ & 0.74 & 11.61 \\
\hline & MEGAN & $0.23 x+9.00$ & 0.15 & 23.53 & $0.32 x+12.14$ & 0.15 & 21.88 \\
\hline
\end{tabular}

${ }^{\mathrm{a}}$ Emission factor Is value is $53 \mu \mathrm{gC} \mathrm{g}_{\mathrm{DM}}^{-1} \mathrm{~h}^{-1}$ (as in Simpson et al., 1999) for all Qpi. ${ }^{\mathrm{b}}$ Emission factor Is value is 72 and $138 \mu \mathrm{gC} \mathrm{g}_{\mathrm{DM}}^{-1} \mathrm{~h}^{-1}(Q p 1$ and $Q p 4$ respectively, this study).

total BVOC) dominated the other emitted BVOCs, but traces of acetaldehyde and acetone were also measured.

For both shaded and sunlit $Q$. pubescens branches, most of the isoprene emission rates exponentially increased with Pn, although Pn was half as much for shaded than sunlit branches. In shaded branches, a very small fraction of the recently assimilated $\mathrm{CO}_{2}\left(\mathrm{C}_{\mathrm{iso}}\right)$ was emitted as isoprene $(0.25-$ $0.5 \%$ ), whereas $\mathrm{C}_{\text {iso }}$ ranged between 0.5 and $1.8 \%$ for sunlit branches with a maximum of $6.7 \%$ under elevated temperature and sunlight stress.

Tree-to-tree isoprene emission variability was high considering the sunlit branches $(n=7)$ and, to a lesser extent, the shaded $(n=2)$ branches. $\mathrm{ER}_{\mathrm{d}}$ sunlit branches varied over a factor of 10 and emission factor Is over a factor of 4.3 (between $31 \pm 8$ and $138 \pm 10 \mu \mathrm{gC} \mathrm{g}_{\mathrm{DM}}^{-1} \mathrm{~h}^{-1}$ ). Shaded branch variability was lower, a factor of 3 for $\mathrm{ER}_{\mathrm{d}}$ (between 4.0 and $13 \mu \mathrm{gC} \mathrm{g}_{\mathrm{DM}}^{-1} \mathrm{~h}^{-1}$ ) and not significant for Is (between $59 \pm 12$ and $\left.77 \pm 3.0 \mu \mathrm{gC} \mathrm{g} \mathrm{gM}_{\mathrm{DM}}^{-1} \mathrm{~h}^{-1}\right)$.

Within the canopy (shaded vs. sunlit branches), $\mathrm{ER}_{\mathrm{d}}$ varied by a factor of 25 . However, this difference between shaded and sunlit branches disappeared when Is was calculated.

Such variability represents an assessment of the tree-totree and branch-to-branch variability originating from in situ conditions that should always be taken into account when canopy BVOC fluxes are extrapolated from branch-scale measurements. Thus, though experiments conducted from saplings grown under near-natural, but controlled, conditions give a fairly straightforward estimation of BVOC emissions by a plant, it cannot give the full picture obtained by in situ long-term measurements.
The morning onset of isoprene emission rates was mainly driven by temperature and not Pn which was, as expected, light triggered. By contrast, evening emissions decline was mainly correlated with PAR. In between, an uncoupling of isoprene emissions with light and temperature was noticed, with emissions starting to decline during the early afternoon temperature stress whereas light and temperature remained stable.

If MEGAN and G93 algorithms succeed in capturing the overall diurnal pattern of isoprene emissions at the $\mathrm{O}_{3} \mathrm{HP}$, they significantly underestimated emissions by an average factor of up to 3, and especially the midday maximum values when an Is other than those assessed for this site was employed. Both algorithms were found to be very sensitive to Is, and showed difficulties in properly assessing detailed isoprene diurnal variations, in particular at dawn and when midday thermal stress occurred. Under water stress, MEGAN performances were even worse due to its inadequate local description of the soil moisture impact on $Q$. pubescens isoprene emissions. When soil moisture was no longer considered, MEGAN performed similarly to the much simpler G93 algorithm for our June study; however, the G93 performance may be significantly reduced compared to MEGAN when seasonal variations are considered.

This comparison illustrates how uncertain global isoprene emission algorithms or models, such as G93 and MEGAN, can be when employed for high temporal resolution air quality prediction in Mediterranean areas. 
Appendix A: Emission factor Is calculation

The empirical relationship used to describe changes in isoprene emission rates $I\left(\mu g \mathrm{~g} \mathrm{gM}_{\mathrm{DM}}^{-1} \mathrm{~h}^{-1}\right)$ vs. light and temperature was as in Guenther et al. (1993):

$I=\mathrm{Is} \times C_{\mathrm{T}} \times C_{\mathrm{L}}$,

where Is is the isoprene emission factor standardised at $T=$ $30^{\circ} \mathrm{C}$ and $\mathrm{PAR}=1000 \mu \mathrm{mol} \mathrm{m}{ }^{-2} \mathrm{~s}^{-1}\left(\mu \mathrm{gC} \mathrm{g} \mathrm{gM}^{-1} \mathrm{~h}^{-1}\right)$ and $C_{\mathrm{L}}$ and $C_{\mathrm{T}}$ are, respectively, light and temperature coefficients defined by

$C_{\mathrm{L}}=\frac{\alpha C_{\mathrm{L} 1} L}{\sqrt{1+\alpha^{2} L^{2}}}$

and

$C_{\mathrm{T}}=\frac{e^{\frac{C_{\mathrm{T} 1}\left(T-T_{\mathrm{S}}\right)}{{ }^{{ }^{T} T_{\mathrm{S}} T}}}}{1+e^{\frac{C_{T 2}\left(T-T_{\mathrm{M}}\right)}{\mathrm{RT}_{\mathrm{S}} T}}}$,

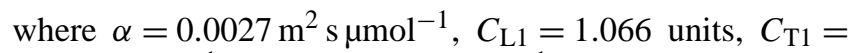
$95000 \mathrm{~J} \mathrm{~mol}^{-1}, C_{\mathrm{T} 2}=230000 \mathrm{~J} \mathrm{~mol}^{-1}, T_{\mathrm{M}}=314 \mathrm{~K}$ are empirically derived constants, $L$ is the photosynthetically active radiation (PAR) flux ( $\mu$ mol(photon) $\mathrm{m}^{-2} \mathrm{~s}^{-1}$ ), $T$ is the predicted temperature $(\mathrm{K})$ and $T_{\mathrm{S}}$ is the leaf temperature at standard condition $(303 \mathrm{~K})$; at standard conditions of $1000 \mu \mathrm{mol}$ (photon) $\mathrm{m}^{-2} \mathrm{~s}^{-1}$ PAR and $303 \mathrm{~K}, C_{\mathrm{T}} \times C_{\mathrm{L}}=1$. 
Acknowledgements. We are very grateful to J.-P. Orts, I. Reiter, P. E. Blanc, J. C. Brunel and other OHP technical staff for support before and during the campaign. We thank D. Coutancier, post-graduate student of IUT d'Orsay for his efficient help in the analysis of LSCE sample tubes and results computing. We thank members of the DFME team from IMBE: S. Greff, C. Lecareux, S. Dupouyet and A. Bousquet-Melou for their help during measurements and analysis. This work was supported by the French National Agency for Research (ANR 2010 JCJC 603 01), INSU (ChARMEx), CNRS National program EC2COBIOEFECT (ICRAM project), CEA, and Université Paris Diderot. We are grateful to FR3098 ECCOREV for the $\mathrm{O}_{3} \mathrm{HP}$ facilities (https://o3hp.obs-hp.fr/index.php/fr/), Europe (FEDER) and ADEME/PACA for PhD funding.

Edited by: J. Rinne

\section{References}

Acherar, M. and Rambal, S.: Comparative water relations of four Mediterranean oak species, Vegetatio, 99-100, 177-184, doi:10.1007/BF00118224, 1992.

Atkinson, R.: Atmospheric chemistry of VOCs and $\mathrm{NO}_{\mathrm{x}}$, Atmos. Environ., 34, 2063-2101, doi:10.1016/S1352-2310(99)00460-4, 2000.

Chen, F. and Dudhia, J.: Coupling an advanced land surfacehydrology model with the Penn State-NCAR MM5 modeling system. Part I: Model implementation and sensitivity, Mon. Weather Rev., 129, 569-585, 2001.

Ciccioli, P., Brancaleoni, E., Frattoni, M., Di Palo, V., Valentini, R., Tirone, G., Seufert, G., Bertin, N., Hansen, U., Csiky, O., Lenz, R., and Sharma, M.: Emission of reactive terpene compounds from orange orchards and their removal by within-canopy processes, J. Geophys. Res.-Atmos., 104, 8077-8094, 1999.

Claeys, M., Graham, B., Vas, G., Wang, W., Vermeylen, R., Pashynska, V., Cafmeyer, J., Guyon, P., Andreae, M. O., Artaxo, P., and Maenhaut, W.: Formation of secondary organic aerosols through photooxidation of isoprene, Science, 303, 1173-1176, doi:10.1126/science.1092805, 2004.

Curci, G., Beekmann, M., Vautard, R., Smiatek, G., Steinbrecher, R., Theloke, J., and Friedrich, R.: Modelling study of the impact of isoprene and terpene biogenic emissions on European ozone levels, J. Atmos. Env., 43, 1444-1455, doi:10.1016/j.atmosenv.2008.02.070, 2009.

Damesin, C. and Rambal, S.: Field study of leaf photosynthetic performance by a Mediterranean deciduous oak tree (Quercus pubescens) during a severe summer drought, New Phytol., 131, 159-167, doi:10.1111/j.1469-8137.1995.tb05717.x, 1995.

Fall R., Karl T., Hansel A., Jordan A., and Lindinger, W.: Volatile organic compounds emitted after leaf wounding: On-line analysis by proton-transfer-reaction mass spectrometry. J. Geophys. Res.-Atmos., 104, 15963-15974, doi:10.1029/1999JD900144, 1999.

Fares, S., Gentner, D. R., Park, J.-H., Ormeno, E., Karlik, J., and Goldstein, A. H.: Biogenic emissions from Citrus species in California, J. Atmos. Env., 45, 4557-4568, doi:10.1016/j.atmosenv.2011.05.066, 2011.
Fortunati, A., Barta, C., Brilli, F., Centritto, M., Zimmer, I., Schnitzler, J. P., and Loreto, F.: Isoprene emission is not temperature-dependent during and after severe drought-stress: a physiological and biochemical analysis, Plant J., 55, 687-697, doi:10.1111/j.1365-313X.2008.03538.x, 2008.

Funk, J. L., Mak, J. E., and Lerdau, M. T.: Stress-induced changes in carbon sources for isoprene production in Populus deltoides, Plant Cell Environ., 27, 747-755, doi:10.1111/j.13653040.2004.01177.x, 2004.

Galbally I. E. and Kirstine W.: The production of methanol by flowering plants and the global cycle of methanol, J. Atmos. Chem., 43, 195-229, 2002.

Guenther, A. B., Monson, R. K., and Fall, R.: Isoprene and monoterpene emission rate variability- Observation with Eucalyptus and emission rate algorithm development, J. Geophys. Res.-Atmos., 96, 10799-10808, doi:10.1029/91JD00960, 1991.

Guenther, A. B., Zimmerman, P. R., Harley, P. C., Monson, R. K., and Fall, R.: Isoprene and Monoterpene Emission Rate Variability - Model Evaluations and Sensitivity Analyses, J. Geophys. Res.-Atmos., 98, 12609-12617, doi:10.1029/93JD00527, 1993.

Guenther, A. B., Zimmerman, P., and Wildermuth, M.: Natural volatile organic compound emission rate estimates for US woodland landscapes, Atmos. Environ., 28, 1197-1210, doi:10.1016/1352-2310(94)90297-6, 1994.

Guenther, A. B, Hewitt, C. N., Erickson, D., Fall, R., Geron, C., Graedel, T., Harley, P., Klinger, L., Lerdau, M., Mckay, W. A., Pierce, T., Scholes, B., Steinbrecher, R., Tallamraju, R., Taylor, J., and Zimmerman, P.: A Global-Model of Natural Volatile Organic-Compound Emissions, J. Geophys. Res.-Atmos, 100, 8873-8892, doi:10.1029/94JD02950, 1995.

Guenther, A., Karl, T., Harley, P., Wiedinmyer, C., Palmer, P. I., and Geron, C.: Estimates of global terrestrial isoprene emissions using MEGAN (Model of Emissions of Gases and Aerosols from Nature), Atmos. Chem. Phys., 6, 3181-3210, doi:10.5194/acp-63181-2006, 2006.

Harley, P., Archer, S., and Guenther, A.: Effects of growth irradiance, nitrogen nutrition and watering regime on photosynthesis, leaf conductance and isoprene emission in leaves of Post Oak, Quercus stellata, Ecol. Soc. America, 75, 87-88, 1994.

Hayward, S., Tani, A., Owen, S. M., and Hewitt, C. N.: Online analysis of volatile organic compound emissions from Sitka spruce (Picea sitchensis), Tree Physiol., 24, 721-728, doi:10.1093/treephys/24.7.721, 2004.

Jardine, K. J., Monson, R. K., Abrell, L., Saleska, S. R., Arneth, A., Jardine, A., Ishida, F. Y., Serrano, A. M. Y., Artaxo, P., and Karl, T.: Within-plant isoprene oxidation confirmed by direct emissions of oxidation products methyl vinyl ketone and methacrolein, Glob. Change Biol., 18, 973-984, doi:10.1111/j.1365-2486.2011.02610.x, 2012.

Kalogridis, C., Gros, V., Sarda-Esteve, R., Langford, B., Loubet, B., Bonsang, B., Bonnaire, N., Nemitz, E., Genard, A.-C., Boissard, C., Fernandez, C., Ormeño, E., Baisnée, D., Reiter, I., and Lathière, J.: Concentrations and fluxes of isoprene and oxygenated VOCs at a French Mediterranean oak forest, Atmos. Chem. Phys., 14, 10085-10102, doi:10.5194/acp-14-10085-2014, 2014.

Keenan, T., Niinemets, Ü., Sabate, S., Gracia, C., and Peñuelas, J.: Process based inventory of isoprenoid emissions from European forests: model comparisons, current knowledge and uncer- 
tainties, Atmos. Chem. Phys., 9, 4053-4076, doi:10.5194/acp-94053-2009, 2009.

Kesselmeier, J. and Staudt, M.: Biogenic Volatile Organic Compounds (VOC): an overview on emission, physiology and ecology, J. Atmos. Chem., 33, 23-88, 1999.

Kesselmeier, J., Bode, K., Schafer, L., Schebeske, G., Wolf, A., Brancaleoni, E., Cecinato, A., Ciccioli, P., Frattoni, M., Dutaur, L., Fugit, J. L., Simon, V., and Torres, L.: Simultaneous field measurements of terpene and isoprene emissions from two dominant Mediterranean oak species in relation to a north American species, Atmos. Environ., 32, 1947-1953, doi:10.1016/S13522310(97)00500-1, 1998.

Loreto, F., Barta, C., Brilli, F., and Nogues, I.: On the induction of volatile organic compound emissions by plants as consequence of wounding or fluctuations of light and temperature, Plant Cell and Env., 29, 1820-1828, doi:10.1111/j.13653040.2006.01561.x, 2006.

Monson, R. K. and Fall, R.: Isoprene Emission from Aspen Leaves?: Influence of Environment and Relation to Photosynthesis and Photorespiration, Plant Physiol., 90, 267-274, doi:10.1104/pp.90.1.267, 1989.

Niinemets, Ü. and Reichstein, M.: Controls on the emission of plant volatiles through stomata: differential sensitivity of emission rates to stomatal closure explained. J. Geophys. Res., 108, 4208, doi:10.1029/2002JD002620, 2003.

Niinemets, Ü., Arneth, A., Kuhn, U., Monson, R. K., Peñuelas, J., and Staudt, M.: The emission factor of volatile isoprenoids: stress, acclimation, and developmental responses, Biogeosciences, 7, 2203-2223, doi:10.5194/bg-7-2203-2010, 2010a.

Niinemets, Ü., Monson, R. K., Arneth, A., Ciccioli, P., Kesselmeier, J., Kuhn, U., Noe, S. M., Peñuelas, J., and Staudt, M.: The leaflevel emission factor of volatile isoprenoids: caveats, model algorithms, response shapes and scaling, Biogeosciences, 7, 18091832, doi:10.5194/bg-7-1809-2010, 2010b.

Owen, S. M., Boissard, C., Hagenlocher, B., and Hewitt, C. N.: Field studies of isoprene emissions from vegetation in the Northwest Mediterranean region, J. Geophys. Res., 103, 25499-25511, doi:10.1029/98JD01817, 1998.
Pollmann, J., Ortega, J., and Helmig, D.: Analysis of atmospheric sesquiterpenes: Sampling losses and mitigation of ozone interferences, Environ. Sci. Technol., 39, 9620-9629, doi:10.1021/es050440w, 2005.

Seco, R., Penuelas, J., and Filella, I.: Short-chain oxygenated VOCs: Emission and uptake by plants and atmospheric sources, sinks, and concentrations, Atmos. Environ., 41, 2477-2499, doi:10.1016/j.atmosenv.2006.11.029, 2007.

Simon, V., Dumergues, L., Bouchou, P., Torres, L., and Lopez, A.: Isoprene emission rates and fluxes measured above a Mediterranean oak (Quercus pubescens) forest, Atmos. Res., 74, 49-63, doi:10.1016/j.atmosres.2004.04.005, 2005.

Simpson, D., Winiwarter, W., Börjesson, G., Cinderby, S., Ferreiro, A., Guenther, A., Hewitt, C. N., Janson, R., Khalil, M. A. K., and Owen, S.: Inventorying emissions from nature in Europe, J. Geophys. Res. Atmos., 104, 8113-8152, doi:10.1029/98JD02747, 1999.

Steinbrecher, R., Contran, N., Gugerli, F., Schnitzler, J.-P., Zimmer, I., Menard, T., and Günthardt-Goerg, M. S.: Inter-and intra-specific variability in isoprene production and photosynthesis of Central European oak species, Plant Biol., 15, 148-156, doi:10.1111/j.1438-8677.2012.00688.x, 2013.

Steiner, A. L. and Goldstein A. H.: Biogenic volatile organic compounds, in: Volatile Organic Compounds in the Atmosphere, edited by: Koppmann, R., Blackwell Publishing Ltd., UK, 82128, 2007.

Tani, A., Tozaki, D., Okumura, M., Nozoe, S., and Hirano, T.: Effect of drought stress on isoprene emission from two major Quercus species native to East Asia, J. Atmos. Environ., 45, 6261-6266, doi:10.1016/j.atmosenv.2011.08.003, 2011.

Von Caemmerer, S. and Farquhar, G. D.: Some relationships between the biochemistry of photosynthesis and the gas exchange rates of leaves, Planta, 153, 376-387, 1981. 